\title{
Marriage Choice Standards for Male Students in Al-Maarif University College
}

\author{
Abdulmunim Jabir Hamid Al-Marsoomi \\ Department of English, Al-Maarif University College, Iraq \\ abdalmonem495@gmail.com
}

\begin{abstract}
KEYWORDS: $\quad$ Standards, Marriage Choice, Students, Al-Maarif University College, Hadith Sharif.
\end{abstract}
Crossref doi https://doi.org/10.51345/.v32i2.359.g222

\begin{abstract}
:
The research aims at knowing the order of the choice standards according to their importance and priorities in marriage used by male students at Al-Maarif University College in the light of hadith Sharif: women got married for four characteristics: wealth, lineage, or religion: choose the one of religion to be the winner. the research also intends to uncover whether there is a relationship between their choice for marriage and some variables such as: study specialization, study stage, economic and social levels. the research took as a sample (264) students from the different departments of the college. Thus, the researcher wrote a questionnaire consisting of (12) items and made sure of their validity and consistency. The results of the work show the order of the four standards according to their priority and preference as follows: the standard of religion is the first, followed by the standard of beauty, and thirdly the standard of lineage, while the standards of wealth come last. as far the relationship between the standard and some variables is concerned, the results show that the order of the choice standards differs according to the different departments of the college and the study specialization. it also differs according to the study stages and similarly differs according to the economic and social levels of the students.
\end{abstract}




\title{
معايير الاختيار في الزواج لدى الطلبة الذكور في كلية المعارف الجامعة
}

\author{
م.م. عبد المنعم جابر حامد المرسومي \\ قسم اللغة الإنكليزية، كلية المعارف الجامعة، العراق \\ abdalmonem495@gmail.com \\ المعايير، الاختيار الزواجي، طلبة، كلية المعارف الجامعة، الحديث النبوي الشريف. \\ الكلمات المفتاحية
}

Crossref doi https://doi.org/10.51345/.v32i2.359.g222



هدف البحث المى التعرف على ترتيب معايير الاختيار في الزواج لدى الطلبة الذكور في كلية المعارف الجامعة حسب تفضيل اولويتها واهميتها لفم في ضوء الحديث النبوي الشريف القائل: (تنكح المرأة لاربع: لمالها او لجمالها او لحسبها او لدينها فاظفر


الدراسي، والمراحل الدراسية، والمستوى الاقتصادي / الاجتماعي للطلبة وقد طبق البحث على عينة مكونة من (264) طالبا موزعين على اقسام الكلية حسب تخصصاقا، واعد الباحث استبانة مكونة من (12) فقرة، وقد تم تأكد الباحث من صدقها وثباتها، واظهرت نتائج البحث ان ترتيب المعايير الأربعة حسب أولوية تفضيلها كانت كالانيّ: ان معيار الدين كان في المرتبة


اما علاقة المعايير ببعض المتغيرات فقد كشفت النتائج ان ترتيب معايير الاختيار يختلف باختلاف اقسام الكلية وتخصصاتا الدراسية، كما انه يختلف باختلاف المراحل الدراسية، ومثل ذلك يختلف باختلاف المستوى الاقتصادي الاجتماعي للطلبة.

المقدمة:

خلق الله تعالى الانسان واستخلفه في الأرض وجعل له من نفسه زوجا يسكن اليها، وارسل رسله


هيء النجاح في الحياة الزوجية وديمومتها وتحقيق أهدافه، ثم دارت الازمان وتقاربت الشعوب بفضل تكنولوجيا العصر واتصالاته، واتسعت حريات الاختيار وازدادت المعايير تعددا وتنوعا، وتعددت طرق الاختيار و تنوعت عبر العصور والاجناس البشرية والمجتمعات وطبقاها وثثافاها، وانبرى علماء النفس والاجتماع و باحثيهم فرصدوا عشرات المعايير فاصبح الشباب في حيرة من امرهم، وها نخن في بحثنا هذا




حديثه الشريف: (تنكح المرأة لاربع: لماها او لجماها او لحسبها او لدينها فاظفر بذات الدين تربت يداك)





ان قرار الزوج بشكل عام، والاختيار في الزواج بشكل خاص من اهم القرارات في حياة الانسان واخطرها، اذ ان هذا القرار سيترتب عليه توافق الاسرة او عدم تو افقها، ونجاح الزواج واستمراره، او فشله، وبالتالي سعادة الاسرة او شقاؤها. لذلك يمكننا القول عندما يقرر الشاب الاختيار في الزواج تعترضه مشكلة تحديد الزوجة المناسبة، اذ لابد من معايير واسس يهتدي ها للاختيار الأمثل، ولعلنا لا نجافي الحقيقة ان قلنا ان الكثير من شبابنا يجهلون تلك المعايير والاسس، اويصعب عليهم تحديدها. ور.ما كانت امنيات اباءنا واجدادنا عندما اقدموا على اختيار الزوجة التي فضلوها على غيرها من النساء ان يحققوا ما يستطيعون من المعايير التي جاءت في الحديث النبوي الشريف القائل: (تنكح المرأة لأربع: لمالها او لجمالها او لحسبها او لدينها فاظفر بذات الدين تربت يداك) (شعبان، فوزي، 2006,25). ولكن الان ليس الامر كذلك بعد ان حدث ما حدث من تغير وتطور في غختلف مناحي الحياة الاجتماعية والاقتصادية والثقافية، وتطور وتنوع اكبر في وسائل الاتصال والتكنولوجيا، وفي متطلبات


العالم الى ما يشبه القرية الكونية الواحدة الصغيرة ان هذا وغيره زاد من مشكلة الاختيار صعوبة وتعقيدا.




وقد قل تدخل الاسرة وضعف دورها فازداد الأسلوب الذاتي في الاختيار الزواجي على الأسلوب الاسري الذي كان سائدا في الماضي القريب، فوضع الشباب امام مشكلة اكبر وحيرة وتردد اعظم وفي صراعات نفسية قاسية في كيف يختار ومن يختار، في ضوء تعدد الصفات المطلوبة وتنوعها لدرجة ان الباحث (شحاته) وضع في بحثه للتعرف على خصال الزوج المفضل (32) صفة للزوجة المفضلة (30)


ويزيد المشكلة تعقيدا جهل الإباء او بتحاهلهم لما يرغبه الأبناء ويفضلونه من معايير عند الاختيار الزواجي




يجهال وتوعية من يتجاهل بأهمية الموضوع وخطورته ولما كان شبابنا الجامعي الذين نريد دراسة معاييرهم 
للاختيار في الزواج مسلمون، وان التراث الإسالامي غني في توجيه الشباب وارشادهم ونصحهم للتصدي لمثل هذه المشكلة وتذليلها فلقد وردت احاديث كثيرة ومنها الحديث الذي سبق ذكره، والذي حدد فيه اربعة معايير هي (المال، والجمال، والحسب، والدين) ورجح معيار الدين وفضله على المعايير الأخرى

و كذلك يمكننا النظر الم مشكلة بحثنا من زاوية أخرى الا وهي الصعوبة التي يواجهها شبابنا في تحديد أي من المعايير الأربعة التي وردت في الحديث النبوي الشريف له الأولوية والافضلية لهم ثم أي منها النذي يليه فالذي يليه و كذلك جهل ذوي العلاقة من أولياء الامر و الباحثين .ما يفضله الشباب من هذه المعايير و خاصة قلة البحوث بل ندرها التي تربط بين الدين وعلم النفس في موضوع معايير الاختيار في الزواج، وهذا ما سيتصدى له بكثنا الحالي، ليتعرف على المشكلة ويكشف عن ترتيب المعايير الأربعة التي حددها الحديث لدى طلبة كلية المعارف الجامعة، ويبين أين موقعهم من هذه المعايير اليت وردت في الحديث الشر يف. ولعل جهلنا بمدى العلاقة بين معايير الاختيار في ضوء الحديث النبوي الشريف وبعض المتغيرات والتي هي (التخصص الدراسي، والمرحلة الدراسية، والمستوى الاقتصادي الاجتماعي) يعد مشكلة سيحاول بكثنا التصدي لها و كشفها وبيان مدى العلاقة بين هذه المتغيرات والاختيار في الزواج.

\section{أهية البحث:}

ان أهمية البحث تاتي من أهمية موضوع البحث وخطورته اذ نستطيع القول ان اغلب علماء علم النفس وعلم الاجتماع وباحثيهم وعلماء الدين وفقهائه يؤكدون ان الاختيار الزوجي السليم احد اهم اركان سعادة الاسرة واستمرار كياها واستقرارها النفسي والاجتماعي والسكينة والامن والطمأنينة، ويزيد من التو افق النفسي والتماسك الاجتماعي والألفة، ويؤدي الم التمتع بالصحة النفسية، ففيه سيجد من يحب ويكبه، ويشبع كثيراً من حاجاته ويكقق ذاته، في حين ان سوء الاختيار في الزواج سيؤدي لا محالة الم التفكك الاسرى او الطلاق نتيجة الاضطرابات في العلاقات الزوجية وسيكون .كثابة ظروف تثير الضغوط النفسية من قبيل الشعور بالعزلة والاغتراب و النبذ وقلة الكفاءة. (القيسي، لما ماجد، 345) ومثل ذلك فان علماء الدين وفقهاؤه تناولوا موضوع الزواج والاختيار في الزواج، ان الإسلام شرع الزواج و حث عليه، وبين المعابير التي يمكن اعتمادها وذلك كما جاء في بعض الآيات والاحاديث النبوية













هذه الايات، وتلك الاحاديث وغيرها، وما توصل اليه علماء النفس وباحثيه تؤكد لنا أهمية دراسة موضوع الاختيار في الزواج وضرورة دراسته.






الشباب وتنير طريقهم وتساعدهم وترشدهم الى أهمية الزواج ستزيد من وعي الولدين لتفهم رغبات أبناءهم واهم تلك المعايير واختيار انسبها. ان اجر اء مثل هذه البحوث قد يكون لها فائدة في تثقيف مختلف فئات المجتمع المحلي بمعايير الاختيار في


وترتيبها في ضوء ما جاء بالحديث النبوي ومعرفة موقع طلابنا من الحمديث له أهمية خاصة، كما ان ونان التعرف على العلاقة بين هذه المعايير وبعض المتغيرات، كالتخصص الدراسي، والمرحلة الدراسية والمستوى الاقتصادي الاجتماعي، لا يقل أهمية عما ذكرنا.

\section{أهداف البحث:}

يسعى البحث الم تحقين الهدف الرئيس، وهو الكشف عن والتعرف على ترتيب معاير الاختيار في


النبوي الشريف القائل: (تنكح المراة لاربع: لماها او لحسبها او لدينها فاظفر بذات الدين تربت يداك). ويتفرع منه الأهداف التالية:

1- التعرف على معايير الاختيار في الزواج التي جاءت في الحلديث حسب اوليتها وتفضيلها وفقا لمتغير التخصص الدراسي الأقسام الكلية التسعة. 2- التعرف على معايير الاختيار في الزواج التي جاءت في الحديث النبوي حسب اوليتها وتفضيلها وفقا المتغير المراحل الدراسية، (الأولى - الثالثة). 3- التعرف على معايير الاختيار في الزواج التي جاءت في الحلديث النبوي حسب اولويتها وفقا لمتغير المستوى الاقتصادي الاجتماعي، للطلاب. 




ان فروض البحث هي الإجابة على التساؤلات الاتية.

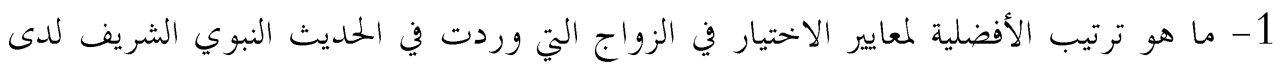

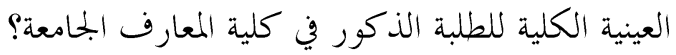
2- هل توجد فروق في الأفضلية لمعايير الاختيار في الزواج التي جاءت في الحلديث النبوي الشريف

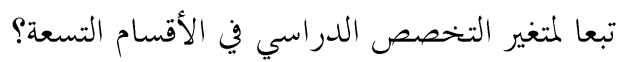
3- هل توجد فروق في الأفضلية لمعايير الاختيار في الزواج التي جاءت في الحلديث النبوي الشريف

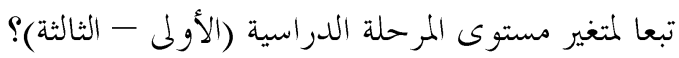

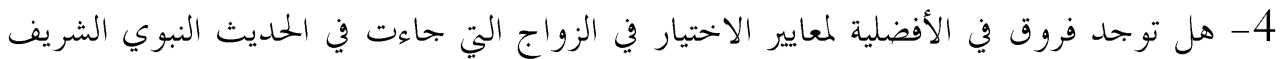

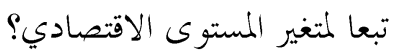

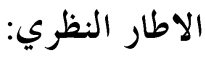



لا يمكن اعتبار الزواج في حد ذاته حدثا بيولوجيا فحسب وان كان الو اقع البيولوجي يهيء لهذه النتيجة




فالزواج نظام حيوي مهم في أي بحتمع انساني، فهو صلة شرعية بين الجنسين من خلال عقد يلتزم به وله

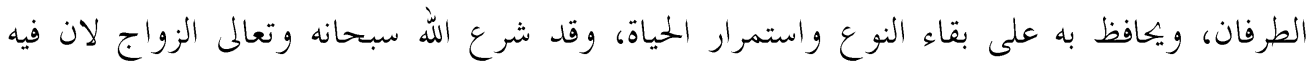




الإسلام الزواج لان الزواج هو اللبنة الأولى لبناء الاسرة فهو أساس البناء والاجتماعي وبه تصان



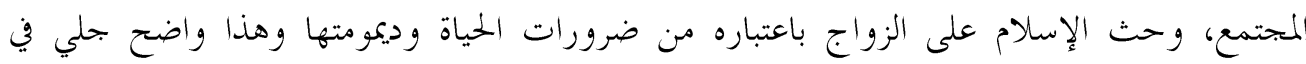
الايات و الاحاديث النبوية الشريفة. 
ورغم تو كيدنا ان لا قول بعد قول الله سبحانه وتعالى ورسوله الكريم، الا اننا نعتقد ان لا ضير ان نبين

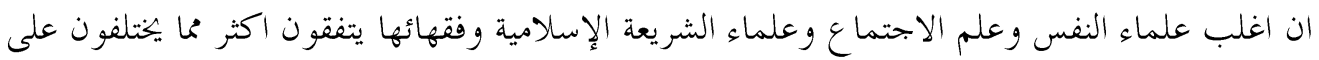
اهمية الزواج وأهدافه التي سنذكر بعضها: 1- سكن النفس وطمأنينتها: لا قول بعد قول الله تعالى حيث جعل من حكمة الزواج تحقيق سكينة


و باحثيهم يعبروا عن أهمية الزواج وأهدافه بالتوافق النفسي والاجتماعي والتمتع بالصحة النفسية

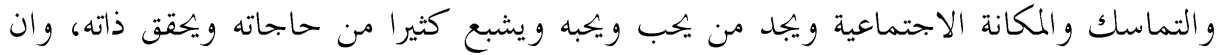
العزوبية والطلاق والترمل .كثابة ظروف تثير عدة ضغوط نفسية من قبيل الشعور بالعزلة والاغتراب و النبذ وقلة الكفاءة، والقلق والخوف، والامراض النفسية (القيسي، لما ماجد ص344). 2- الاعفاف و التحصين: وهو على نوعين الأول ان الإسلام وعلم النفس جعل من الزواج وقاية من


ويكصنهما من الشطط ودواعيه. اما التحصين الثاني فان الزواج وقاية وتحصين من الامراض


التي اكد العلم الحديث ان سببه وطرق عدواه هو الاتصال الجنسي المنحرف.

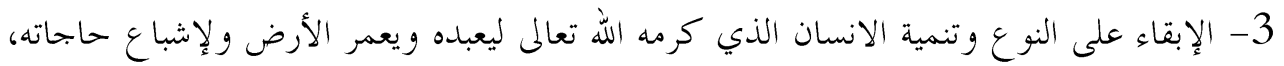

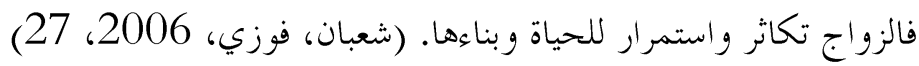

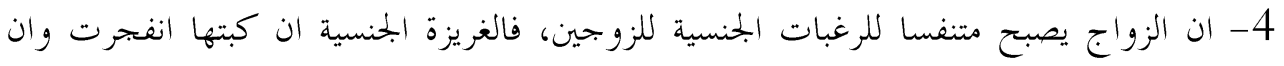

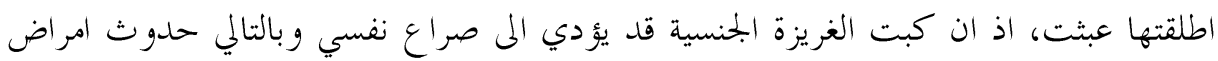


تخاطر نفسية واجتماعية اذ لابد ان يشعر بالقلق والندم والاضطراب النفسي ناهيك عن الامراض العضوية التي تنتقل عن طريق الجهاز التناسلي، وبالتالي ففي الزواج حماية الاعراض والانساب






\section{ثانيا: الاختيار في الزواج نظرياته ومعاييره:}

\section{أ- أساليب الاختيار:}

يقصد هِا الأساليب المفضلة للاختيار في الزواج سواء بتدخل اشخاص اخرين في عملية الاختيار، او عدم

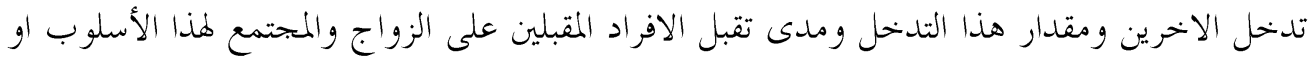
ذلك، وليس من شك ان اول أسس بناح الزواج وتو افقه هو حسن الاختيار، الذي سيكون عماد البناء الاسري والذي يبدو لنا ان هناك نمطين سائدين عند الاختيار: 1- الاختيار الاسرى (الاجتماعي) وهو ذلك النمط الذي يسمح بتدخل الاسرة او افراد اخرين من أقرباء الشريكين، وهو النمط الذي تقوم الاسرة بترتيب اغلب الأمور ان لم نقل جميعها، وقد أند

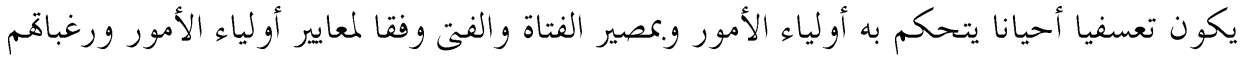



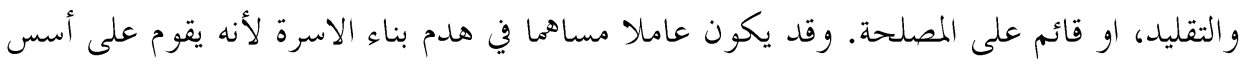




تعرض عن نفسها، وذان البكر صمتها) (شعبان، فوزي، المصدر السابق).




تتدخل فائيا، وهو أسلوب شاع ظهوره نتيجة للظروف الثقافية والاجتماعية والاقتصادية والاعلام والتأثر بنمط الحياة الغربية، وهو نمط بدأ يتسع وينتشر بصيغ شتى في المجتمعات العربية والإسلامية، وهو نتيجة واقعه لا عحالة لتغليب النمط الاسرى وللتشدد والتعسف الو اقع منه غالبا.

\section{ب- نظريات الاختيار في الزواج النفسية والاجتماعية:}

هناك عدد من النظريات النفسية والاجتماعية حاولت تفسير عملية الاختيار في الزواج ومعاييره منها: 1- نظرية الحاجات التكميلية: كان ل(روبرت ونش) السبق والفضل لوضع أسس هذه النظرية، ثم

تناول كثير من العلماء والباحثين مسالة التجاذب التكميلي او التناغم للحاجات، فلقد أشار (او همان) اننا ننجذب نغو الذين نحتاج اليهم ليكملونا سيكولو جيا، فنحمن نبحث عن شريك الحياة




اشباعا لحاجتها الى السيطرة سوف تمضي في رغبتها في السيطرة عليه، وقد يظهر التكميل للحاجات بين شخصين الأول على سبيل المثال يريد من الاخرين السمع والطاعة (أي عنده حاجة شديدة للسيطرة) و الثاني فاقد القدرة على تسيير اموره وييحث عمن يرشده أي طريق يسلك لديه حاجة ضئيلة ومنخفضة جداً للسيطرة. اما (دور كهايم) فيشير الى اننا نحب من يفكرون ويشعرون بما نفكر نخ ونشعر، لذا فنحن ننجذب نهو هولاء الذين يكملون أوجه النقص فينا، لاهم يشعرون باهم اكثر تكاملا من ذي قبل، أي ان الأشخاص الذين لديهم تكوينات نفسية تكميلية ينجذب بعضهم الى بعض وان التفاهم يحدث بين هؤلاء الذين يكمل

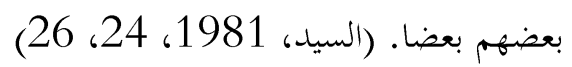

2- نظرية الشريك المثالي: ويقصد (شورس) بالشريك المثالي او النموذج تلك الصورة التي تتكون للدى الفرد في سن الزواج عن نمط الشخص الذي يود الزواج منه، وهذه الصورة نطلق عليها في لغتنا العادية (فتاة الاحلام، فتى الاحلام) ويرى (كرستنسن) ان معظم الناس منذ طفولتهم المبكرة حتى وقت زواجهم يكونون صورة او فكرة معينة عما يودون ان تكون عليه شريكتهم في الخياة، وان مفهوم الطرف الاخر المثالي ينبثق تدريجيا عند الفرد حين يتعامل مع ابويه واخوانه واخواته، ثم مع اخرين في المجتمع، وهو يتبلور من خلال أنماط العادات والحاجات الشخصية، اها تنطوي على تلك الصورة الرومانتيكية على وصف شامل للطرف الاخر من حيث الشكل والصفات العقلية والمزاجية والوجدانية والأخلاقية والاجتماعية المفضلة اليه. (burgess 1965 p.p 364) 3- نظرية التجانس والتشابه: وتعني ان الناس يميلون شعوريا أولا شعوريا لاختيار شريك حياة تتشابه خصائصه مع خصائصهم، أي ان هناك تشابه وبتحانس بين الشريكين في الدين، والسن، و التعليم والمهنة والاصل، و المستوى الاقتصادي والاجتماعي، فهذا سيزيد من التوافق النفسي و الاجتماعي والاسري ويشعر الشريكين بالأمن والطمأنينة والانسجام وبالتالي الى زواج ناجح


4- نظرية الصورة الوالدية: من العلماء والباحثين من يرى ان الصورة الوالدية (الوالد، الوالدة) تلعب دورا جوهريا في عملية اختيار شريك الحياة للزواج أي ان الشباب ييحث في شريك حياته صفات وخصائص و الدته، و الفتاة تبحث عن صفات و خصائص والدها في شريك حياتها. 


\section{ت- معايير الاختيار في الزواج:}

لما كان قصدنا بمعايير الاختيار في الزواج باها بحموعة من العوامل او الصفات التي يفضلها الفرد في


وباحثيه، بل وحتى ما قاله علماء الشريعة وفقهاءها، فيما جاء في الاطار النظري والدراسات السابقة


الاختيار، وبعضهم اسماها عو امل الاختيار، اوالصفات والخصائص المطلوبة في الشريك، في حين سماها


هناك معايير او أسس او صفات كثيرة متعلدة ومتنوعة وصل في بعض الدراسات الى العشرات، فهذا مثلا (شحاته) 1992 في بحثه الذي هدف فيه الى التعرف على خصال الزواج المفضل لطلاب وطالبات الجامعة تضمنت (32) صفة للزوجة و(30) صفة للزوج، ومثل ذلك في دراسة (سبرشر) تضمنت (12) صفة لشريك الحياة، ور.ما تبقى القائمة مفتوحة مع تطور الزمان و الماكان و الظروف، ونه واذا ما اردنا ان نذكر بعض تلك المعايير او الصفات التي وردت في بعض الدراسات والنظريات سنجدها عديدة

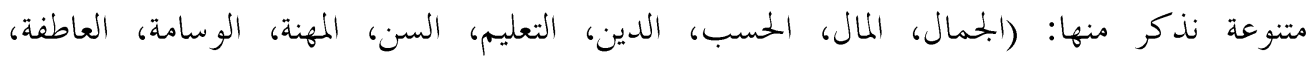

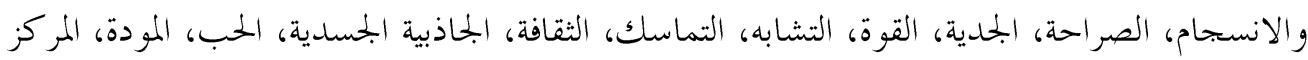

$$
\text { الاجتماعي او الاقتصادي....... }
$$

وسنوضح اهم تلك المعايير التي يتفق عليها اغلب علماء النفس وعلم الاجتماع وباحثيهم والكثير من علماء الدين التي هيء أساس النجاح في الحياة الزوجية، ويعتبروها شروطا يجب الالتزام هـا عند التخاذ قرار الزواج منها:

1- الدين: نحن المسلمون نعتقد ان الزواج بمسلمة افضل من الزواج بكتابية وان كان الزواج بكتابية

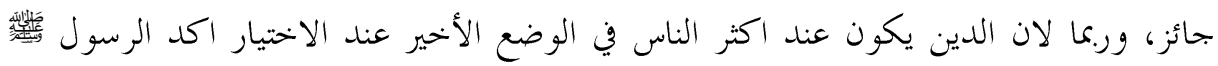
على طالب الزواج ان يفضل ذات الدين على غيرها، وان يلتفت الى الدين قبل سواه لمن يريدها زوجة له، واما لأبنائه وليس القصد في الدين ان تقوم بالعبادات صلاة وصوم مثلا فحسب، ولى وانما

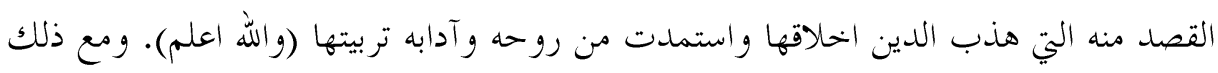

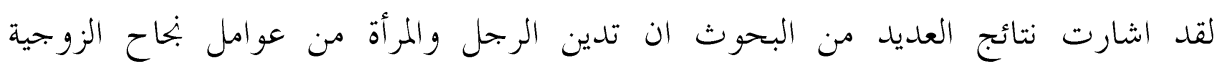
واستقرارها. (مرسي 1994) ولقد بينا اهم الآيات والاحاديث فيما سبق. 
2- النضج والقدرة على تحمل المسؤولية: يفضل قبل القرار معرفه مستوى نضج شريك الحياة

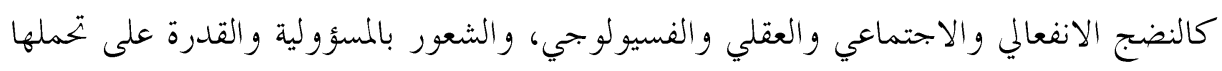













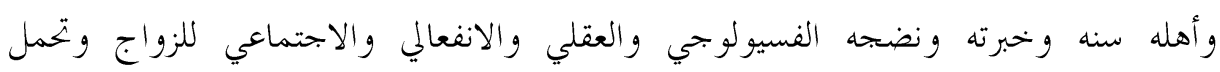



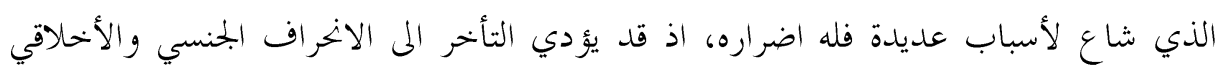



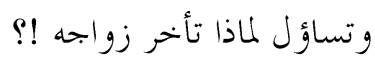

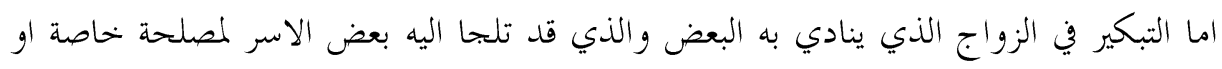
















4- التجانس والتشابه: يفضل عند اختيار الشريك مراعاة التجانس والتشابه في الخلفية الاجتماعية





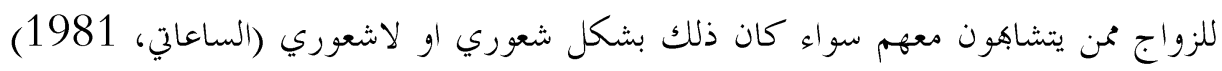


فيحبذ ان يكون الزوجان متكافئين في المستوى الاقتصادي والاجتماعي حتى لا تتغير حال المرأة

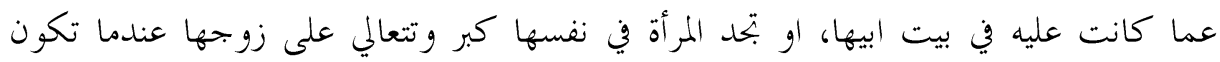
افضل منه اقتصاديا واجتماعيا.

5- سمات الشخصية: تشير البحوث الى ان الذكور يفضلون اختيار الزوجة التي تتسم ببعض النص السمات مثل الجاذبية الجمسدية والوجه الجمميل، والمطيعة والودودة، وغير الانانية بينما تفضل

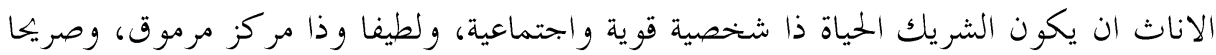

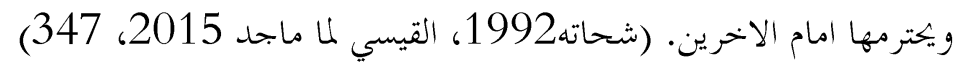

6- التقارب والتجاور المكابي: يميل بعض الأشخاص الى اختيار زوجاهمم من الأماكن القريبة منهم، لان القرب المكاني يتيح فرصة التعرف على السمات والخصائص الشخصية والاجتماعية بشكل

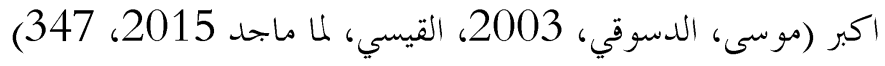

ثالثا: الدراسات السابقة SIX different in human mate preferences دراسة 1989 1989 وكانت بعنوان evolutionary hypothec tested in 37 cultures

هدفت الدراسة الى معرفة المعايير الأساسية لاختيار شريك الحياة، اذ تم تطبيقها على (10047) فرداً من 37 دولة وثقافات مختلفة وتوصلت الدراسة الى ان خمسة معايير أساسية لاختيار شريك الحياة هي: (القدرة على كسب الموارد الاقتصادية، والطموح والاصرار على النجاح في العمل، والشباب والحيوية،

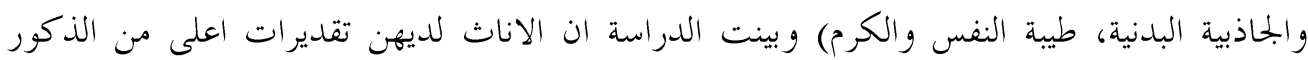
بخصوص أهمية معيار القدرة على كسب الموارد الاقتصادية لدى شريك الحياة، بينما يقدر الذكور المعايير المتعلقة بالإنجاب والشباب والحيوية والجاذبية البدنية (1989 19uss)

2- 2 بحث شحاته:1992

هدف البحث الى التعرف على خصال الزوج المفضل لطالبات الجامعة وطلاها، وقد طبق البحث على عينة تكونت من (313) من طلاب وطالبات جامعة المنوفية، وقد وجه الباحث للمفحوصين قائمتين تشمل القائمة الأولى على (32) صفة للزوجة، وتشمل القائمة الأخرى على (30) صفة للز لزونه






الذكور، اما صفات الزوج المفضل للى الاناث احترام الزوجة امام الاخرين، والالتزام بأحكام الدين، و ان يشعر الزوجة بكياها كامرأة والجدية في التصرفات، والصراحة (القيسي، لما ماجد 2015، 350)

\section{3- بحث كل من: سبرشر وسوليفان و هافليد 1994}

هدف البحث التعرف على معايير الاختيار الزواجي للى عينة تكونت من (329) أمريكيا من الجنسين جميعهم غير متزوجين تمتد أعمارهم من (19-35) سنة، طلب منهم تقدير مدى موافقتهم على (12) صفة لشريك الحياة، وكشفت نتائج البحث ان الاختيار في الزواج يتم على أساس، العمر والمكانة العلمية، والمهنة والمظهر الشخصي، كما تبين ان رغبة الاناث في الزواج كمن هو اقل منهن وسامة واكبر منهن عمرا بخمس سنوات ومن مستوى تعليمي ومهني اعلى، بينما يفضل الذكور .كن هن اكثر همالا واصغر منهم سنا بخمسة أعوام ومن مستوى تعليمي اقل، وليس من الضرورة ان تكون عاملة. (القيسي، (348 U ماجد

\section{4- دراسة عطيات أبو العينين، 1999:}

كانت بعنوان (ديناميات الاختيار الزواجي وعلاقته ببعض المتغيرات النفسية والاجتماعية) وهدفت الدراسة التعرف والكشف عما اذا كان للى الشباب الجامعي مكات للاختيار الزواجي وما هي هذه المحكات، وتوصلت الدراسة الى نتائج أهمها: ان الشباب يؤكدون على ستة محكات هي: (المحك الشكلي - المادي - النفسي - الاجتماعي - المحك الديني - الفكري و الثقافي) وقد ثبت و جود فروق دالة بين الطلبة على المحك الفكري لصالح الذكور، والديني لصالح الاناث، كما وجدت فروقا دالة على المحك الشكلي والنفسي والاجتماعي والفكري والثقافي لصالح الكليات العلمية (أبو العينين، عطيات، (182،1999

\section{Chuang 2002 -5 بحث شانج:}

هدف البحث لمعرفة الفروق بين الجنسين في تفضيلات الاختيار الزواجي على عينه مكونة من (644) من طلاب الجامعات في الصين منهم (278) ذكورا و(366) اناثا، وبينت النتائج ان الاناث اكثر تعبيرا عن تفضيلات تتعلق .عا سيحصلن عليه، اما الذكور فهم اكثر تفضيلا لجمال المظهر والجمال الجمسدي، كما أظهرت النتائج ان الذكور اكثر تفضيلا للقدرة على الانسجام والاتفاق في التوجه، اما الاناث فهن اكثر تفضيلا للمبادئ الأخحافية (القيسي، للا ماجد 2015، 348) 6-6 
بحث للتعرف على معايير الاختيار الزواجي ومستوى الرضا بين الامريكين والهنود و كانت عينة البحث


فروق جوهرية بين الامريكين والهنود من حيث معايير الاختيار، فالهنود اكثر تفضيلا لتو افر مواصفات الحبب والإخلاص والالتزام، اما الامريكين فهم اكثر تفضيلا للمواصفات المادية المحسوسة كسمات الشخصية والمظهر والثراء، كما تبين وجود فروق ذات دلالة إحصائية في مشاركة الاسرة في عملية الاختيار لصالح الاسرة الهندية على اعتبار ان الاسرة الهندية تفرض رايها في اختيار الزوج. (القيسي، لمانس ماجد، 2015، 348)

\section{Badahdah and tieann 2005 دراسة بدهدا وتايمان}

قاما يبحث هدف الى التعرف على معايير اختيار الزوج لدى المسلمين المغتربين واستخدم الباحث المنهج

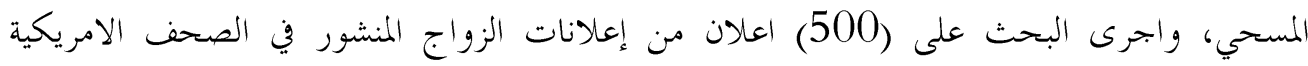

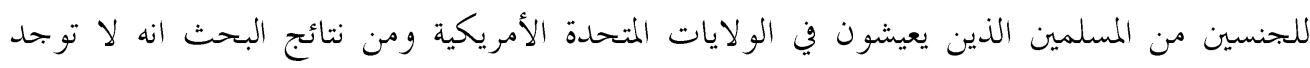
فروق بين الجنسين فيما يتعلق بالجاذبية للشريك، وان الجنسين يفضلون الشريك الملتزم دينيا، وتفضل

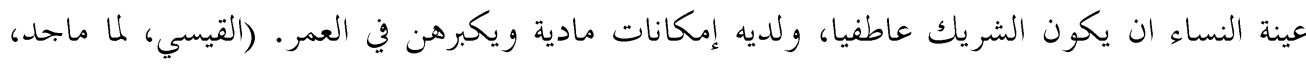

(348، 2015

\section{8- بحث درويش زينب (2009):}

كانت بعنوان (محكات اختيار شريك الحياة وعلاقتها ببعض المتغيرات النفسية لدى الطلاب الجامعة السعوديين و المصريين)، وهدفت الدراسة الى تحديد محكات اختيار شريك الحياة لدى الطلاب الجامعة

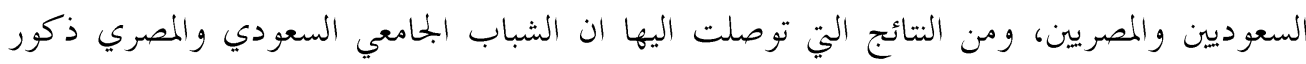


الادب والأخلاق، والمى وجود علاقة جوهرية بين المحك النفسي والاجتماعي والمادي والثقافي ومحك الثك

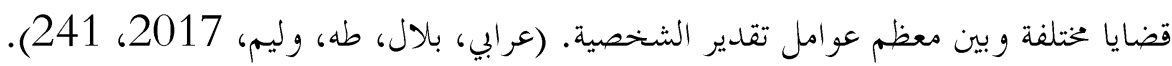
9- بحث ماليكي: (Malki 2010)

هدف البحث الى التعرف على أسس اختيار الزواج لدى طلاب جامعات نيجيرية، تكونت عينة

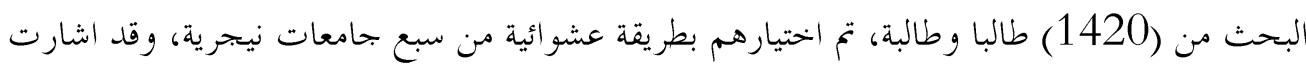

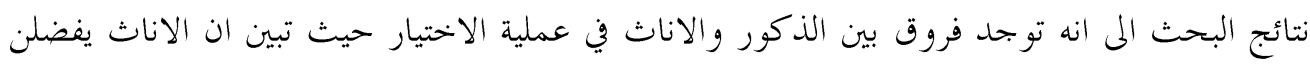
اختيار شريك الحياة بناء على المكانة الاقتصادية والاجتماعية المرموقة بينما يفضل الذكور اختيار الزوجة 
بناء على الجاذبية الجسدية وجمال الوجه اكثر من التركيز على وضعها الاقتصادي والاجتماعي. (القيسي، لما بحله، (1)

\section{0- دراسة القيسي لما ماجد:2015}

هدف البحث الم التعرف على الاختيار الزواجي من وجهة نظر عينة من طلبة جامعة الطفيلية التقنية ومدر كاهم لأهمية حرية الاختيار ومعاييره ومعيقاته، وقد تكونت عينة البحث من (268) طالبا وطالبة، واستخدمت الباحثة استبانه مكونه من (22) فقرة لجمع البيانات، وقد تم التأكد من صدقها وثباتا، وأشارت نتائج البحث الى ان الطلاب يعطون قيمة عالية لأهمية حرية الاختيار، اما بالنسبة لمعايير الاختيار فقد عبر افراد العينية عن استجابات عالية على فقرات الشعور بالحب والمظهر الخارجي والعمر والجاذبية الجسدية في تفضيلات الاختيار، فكانت استجابات الطلاب مرتفعة على الوضع الاقتصادي، وتقاليد الاسرة، كما أظهرت النتائج انه لاتوجد فروق ذات دلالة إحصائية على بعدي حرية الاختيار ومعاييره تعزى للجنس والكلية ومكان الإقامة، بينما توجد فروق ذات دلالة إحصائية لبعد صعوبات الاختيار تعزى لمتغير الكلية فكانت لصالح الكليات العلمية. (القيسي، لما ماجد، 2015، 343) 11- دراسة عرابي، بلال، طه وليم: 2017 هدفت الدراسة الم تحليل المضمون لاهم المعايير المفضلة عند اختيار شريك الحياة لدى طلبة جامعتي دمشق الحكومية واليرموك الخاصة، و معرفتها و مقارنتها، وترتيبها حسب أهميتها في ضوء بعض المتغيرات الديموغرافية هم (نوع الجامعة، الجنس، السنة الدراسية) وكانت أداة البحث الاستبانة وهي مقننة و مضبوطة من حيث الأسئلة الواردة فيها، واظهرت الدراسة نتائج ملخصها: ان اهم المعايير في اختيار شريك الحياة واولها هو معيار الاخحلاق العالية بنسبة (72,2 7\%) من اجمالي العينة ذكورا واناثا، وبالنسبة للذكور ان (84,9\%) من اجمالي عدد الذكور في الجامعتين يرغبون هذا المعيار مقابل (267,6\% من الاناث، وجاء معيار الحالة الصحية الجيدة في المرتبة الأخيرة بنسبة (15,5\%) من اجمالي العينة الكلية، فكانت نسبة الذكور (11,3\%) تحبذ هذا المعيار مقابل (17\%) من الاناث واقترحت الدراسة انشاء مراكز متخصصة للارشاد الزواجي تابعا للجامعات تعبي بتقليم خدمات الارشاد الزواجي والاسري قبل وبعد الزواج بالنسبة للشباب عامة والجامعي خاصة، وإقامة ندوات توعوية وتلريبية للتعامل مع حالات اختيار شريك الحياة يستفيد منها الشباب المقبل على الزواج.

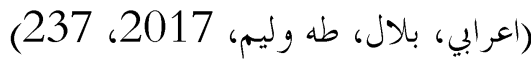
تعقيب على الدراسات السابقة: 
1- تشاهت نتائج بعض الدراسات السابقة رغم اختلاف المجتمعات والبلدان في بعض المحكات والصفات المطلوبة عند الاختيار كما في دراسة (بوس) ل(37) دولة ودراسة (درويش) بين المصريين والسعوديين بينما اختلفت نتائج بعض الدراسات باختلاف المجتمعات والبلدان كما في دراسة (ماير) التي وجدت فروق واضحة بين الأمريكيين والهنود.

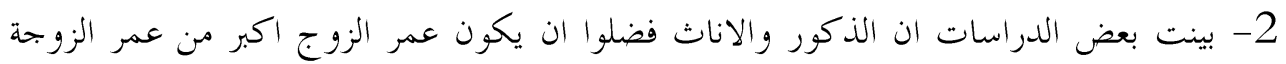
ب(5) خمس سنوات، والمستوى التعليمي والمهين للزوج اعلى من المستوى التعليمي والمهين للزوجة، كما في بحث (سبرشر وسوليفان، ودراسة بدهدا وتايمان).

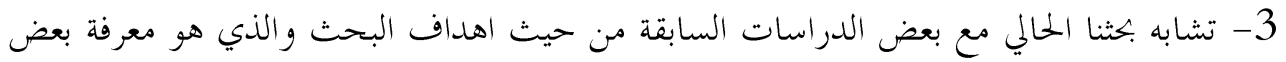
معايير واسس الاختيار في الزواج، وكذلك في استخدام المنهج الوصفي، وكذلك تشابه في إداة

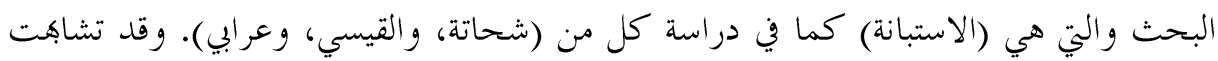

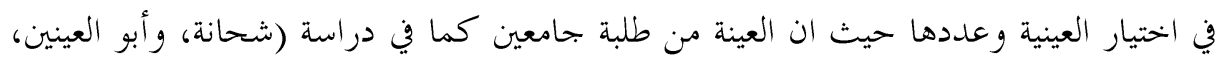
وشانج، ودرويش، القيسي، وعرابي). 4- تشاهت نتائج كثير من الدراسات في ان اهم معايير اختيار الزوجة للزورجي هي الاخلاق والمظهر، والدين، والتعليم، والوضع الاقتصادي والاجتماعي والوسامة وان اهم معايير اختيار الزوج للزوجة هي (المظهر الخارجي، الجاذبية البدنية القوام الطاعة، الدين، العمر والشباب والحيوية والابخاب). 5- ان معايير الجمال قد تختلف من شخص لاخر، حتى وان كانت هنالك معايير يتفق عليها كثير من الافراد ولكن يبقى هناك من يرى الاخر جميل قد يراه غيره ليس جميلا.

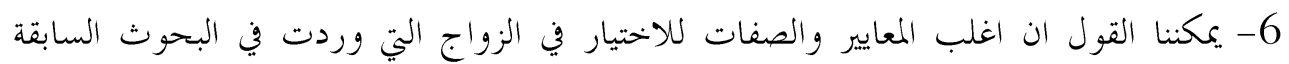
تتضمنها المعايير الأربعة التي وردت في الحديث النبوي الشريف فمثلا (المظهر الشخصي الجحاذبية

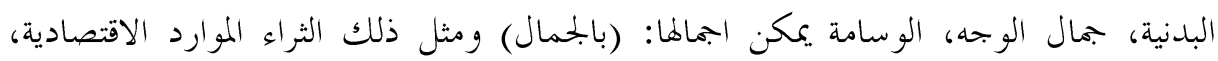

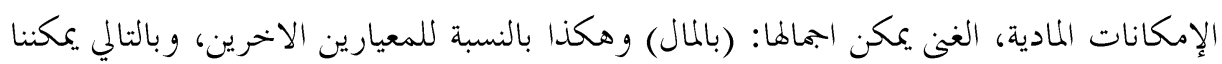
القول ان ما ورد في الحلديث النبوي الشريف هي معايير شاملة.

إجراءات البحث: أولا: منهجية البحث: استخدم المنهج الوصفي لهذا البحث حيث تم استخدام الاستبانة التي اعدها الباحث لقياس درجة تفضيل طلاب كلية المعارف الجامعة، لمعايير الاختيار في الزواج، المحددة في 
الحديث الشريف القائل: (تنكح المرأة لاربع لماها او لجماها او لحسبها او لدينها فاظفر بذات الدين تربت يداك). ثانيا: مجتمع البحث: تكون بحتمع البحث من الطلاب الذكور في كلية المعارف الجامعة للعام الدراسي

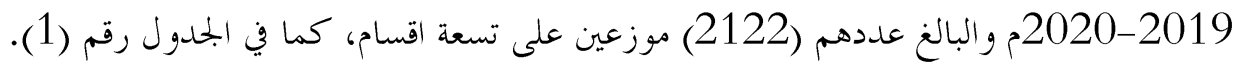
جدول رقم (1) يبين بحتمع البحث للمراحل الدراسية في كافة لأقسام (الذكور فقط)

\begin{tabular}{|c|c|c|c|c|c|c|}
\hline المجموع ع & المرابعة & الثالثة & الثانية & الأولى & القسم & ت \\
\hline 83 & 33 & 22 & 12 & 16 & اللغة العربية & 1 \\
\hline 186 & 45 & 46 & 47 & 48 & اللغة الإنكليزية & 2 \\
\hline 488 & 103 & 147 & 120 & 118 & القانون & 3 \\
\hline 252 & & 96 & 178 & 78 & تحليلات مرضية & 4 \\
\hline 475 & 114 & 127 & 129 & 105 & مالية مصرفية & 5 \\
\hline 74 & & 25 & 26 & 23 & هندسة مدنية & 6 \\
\hline 220 & 82 & 64 & 42 & 32 & تقنيات حاسوب & 7 \\
\hline 89 & 28 & 16 & 22 & 23 & علوم حاسوب & 8 \\
\hline 255 & & 99 & 96 & 60 & تربية بدنية & 9 \\
\hline 2122 & 405 & 642 & 572 & 503 & المجموع & \\
\hline
\end{tabular}

ثالثا: عينة البحث: لتحقيق اهداف البحث ثم اعتماد العينة العشوائية البسيطة حيث تم اختيار عينة عشو ائية من بحتمع البحث بلغ عددها (264) طالبا من المرحلة الأولى والثالثة وقد حدد الباحث المرحلة

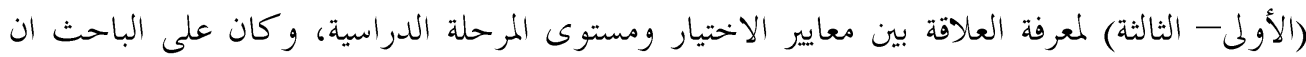

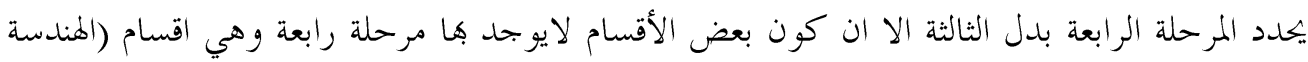
المدنية وتقنيات التحليلات المرضية، والتربية البدنية) اضطر لاختيار المرحلة الثالثة لتشمل العينة جميع الأقسام وشكلت 12\% من بحتمع البحث و كانت كما مبين في الجلدول رقم (2). 


\begin{tabular}{|c|c|c|c|c|}
\hline المجموع & الثالثة & الأول & الأقسام & ت \\
\hline 19 & 10 & 9 & اللغة العربية & 1 \\
\hline 28 & 14 & 14 & اللغة الإنكليزية & 2 \\
\hline 46 & 21 & 19 & القانون & 3 \\
\hline 35 & 19 & 16 & تحليلات مرضية & 4 \\
\hline 37 & 21 & 16 & مالية مصرفية & 5 \\
\hline 21 & 10 & 11 & هندسة مدنية & 6 \\
\hline 31 & 16 & 15 & تقنيات حاسوب & 7 \\
\hline 21 & 10 & 11 & علوم حاسوب & 8 \\
\hline 32 & 17 & 15 & تربية بدنية & 9 \\
\hline 264 & 138 & 126 & المجموع & \\
\hline
\end{tabular}

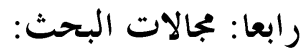

1- المجال المكاني: كلية المعارف الجامعة - الأنبار - العراق. 2- المجال الزماني: من: 2019/10/20 إلى: 2019/12/25

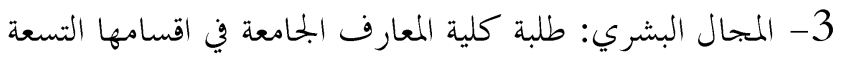
خامسا: أداة البحث: في ضوء اهداف البحث وبعد الاطلاع الباحث على بعض أدوات الدراسات

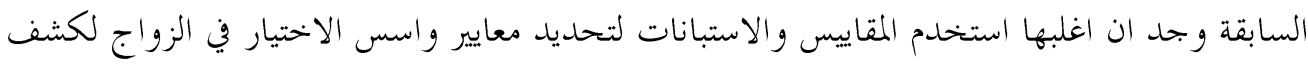
ومعرفة والصفات والخصائص المفضلة والمطلوب توفرها في الزوج او الزوجة وقد وجدنا ان بعض الدراسات اكتفى بعدد محدود منها في حين وصل في بكوث اخرى الى العشرات، ولما كان بكثنا حدد

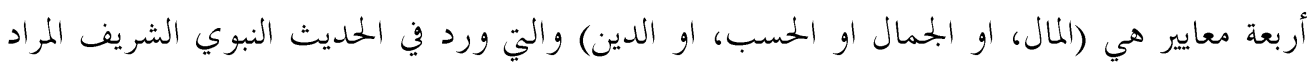

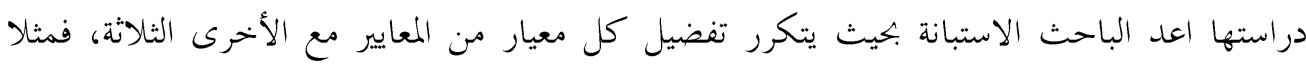

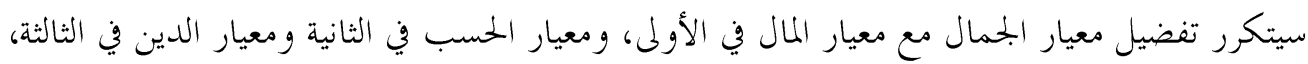
وهكذا مع المعايير الأخرى وهذا اصبح عدد فقرات المقياس (12) فقرة ثم أجرينا له الصدق و الثبات فتم

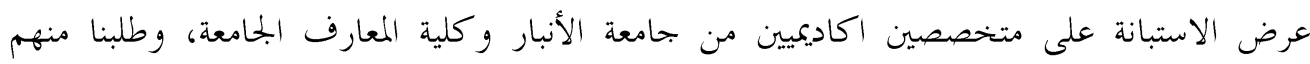
تحكيمه وبيان رايهم فيما اذا كانت الاستبانة تقيس ابعاد الاختيار في الزواج المطلوب قياسها، وابداء الملاحظات التي يروها مناسبة و لم يبدى أي منهم اعتراضا او ملاحظة او تعديلا او إضافة فكانت نسبة إنسات

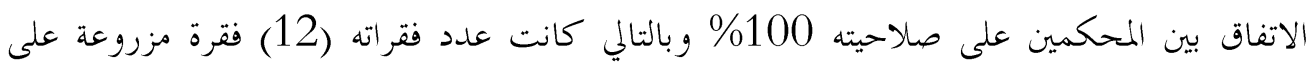


الابعاد الأربعة التي وردت في الحديث الشريف. (ملحق رقم (1) أسماء المحكمين). اما بالنسبة للثبات فتد تم اختيار طريقهم اعادة تطبيق الاستبانة على (15) طالبا بعد ثناثة أسابيع من التطبيق الأول قد تبين ان معامل الارتباط كان 80,0 و هذه النتائج بتعلنا نطمئن على صدقه و ثباته، وصلاحية استخدامه. (ملحق رقم (2) الاستبيان بصورته النهائية) سادساً: الوسائل الإحصائية: من اجل معالجة البيانات إحصائيا استخدام الباحث النسبة المئوية لاعتقاده اها الوسيلة الأمثل لتحقيق اهداف البحث وقد استخدمها بعض الباحثين في بكوثهم كما استخدم المتو سط الحسابي كو سيلة إحصائية ثانية.

نتائج البحث وتفسيرها:

\section{أولا: نتائج العينة الكلية:}

لتحقيق الهدف الأول والفرضية الأولى قمنا بتفريغ البيانات وتبويبها وفقا لاهداف البحث وفرضياته، واستخدام النسبة المئوية كوسيلة إحصائية لكل معيار من معايير الاختيار الزواجي الأربعة ولكل قسم من اقسام الكلية التسعة، ثم تم استخراج النسبة المئوية لكل معيار في كل الأقسام ثم استخرجنا المتوسط الحسابي للنسبة المئوية للاقسام بحتمعة فكانت النتائج كما مبين في الجلدول رقم (3).

جدول رقم (3) يبين النسب المئوية لمعايير الاختيار في الزواج للعينة الكلية

\begin{tabular}{|c|c|c|c|c|c|}
\hline الدين & $\begin{array}{l}\text { الخسب } \\
\text { \% }\end{array}$ & $\begin{array}{l}\text { المال } \\
\%\end{array}$ & $\begin{array}{c}\text { الجمال } \\
\%\end{array}$ & المعايير & ت \\
\hline 64.59 & 44.95 & 21.17 & 48.75 & اللغة العربية & 1 \\
\hline 78.57 & 55.98 & 14.61 & 50.00 & اللغة الإنكليزية & 2 \\
\hline 66.50 & 54.92 & 21.43 & 47.75 & القانون & 3 \\
\hline 78.40 & 47.65 & 13.67 & 57.07 & التحليلات المرضية & 4 \\
\hline 61.85 & 59.87 & 11.41 & 53.70 & المالية المصرفية & 5 \\
\hline 53.34 & 44.39 & 22.73 & 78.03 & الهندسة المدنية & 6 \\
\hline 80.42 & 50.42 & 9.93 & 52.71 & تقنيات حاسوب & 7 \\
\hline 63.42 & 60.46 & 16.21 & 51.06 & علوم حاسوب & 8 \\
\hline 78.27 & 48.73 & 13.03 & 52.75 & تربية بدنية & 9 \\
\hline 69.51 & 51.93 & 16.02 & 54.65 & المتوسط الحسابي للنسبة المئوية & 10 \\
\hline
\end{tabular}


يبين الجحدول السابق رقم (3) -في ضوء الهدف الرئيسي الذي عبرنا عنه في الفرضية الأولى- ان معيار الدين كان في المرتبة الأولى حيث بلغ المتوسط الحسابي للنسبة المئوية (69.51\%) يليه عبديه معيار الجمال

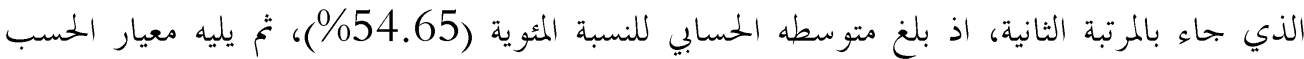

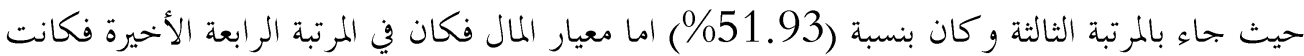
النسبة المئوية (16.02\%) ان تفضيل الدين كأول معيار للاختيار في الزواج يدل على تمسك الطلاب بالقيم الدينية الإسلامية، ان هذا الامر قد لا يكون مستغربا لان طلاب الكلية عاشو طفولتهم ومر اهقتهم في بيئة اسرية اجتماعية إسلامية تحث وتامر للالتزام بالدين وبتعله أساس كل عمل يريدون تحقيقه، فنستطيع القول ان الطلاب ورثوا القيم الدينية كما ورثها اسلافهم المتدينين الذين يؤكدون على اختيار (بنت الحلال) وان اهم مقومات سعادة الانسان في (زوجة صالحة، ورزق حلال) والمقصود بذلك ذات الدين، ان الدين كامن في أعماق نفوسهم مهما ظهر من مظاهر الخضارة واستخدام ادواتا من ماكل وملبس وهاتف، اذيميل كثير من الفلاسفة والعلماء الى القول بان النفس البشرية تحتاج الى التدين كمثل مهن مهن

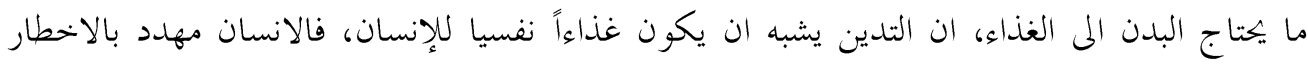
والمشاكل فهو اذن بحاجة الى عقيدة وطقوس دينية تساعده على مواجهة تلك الأمور الصعبة وعلى تقوية

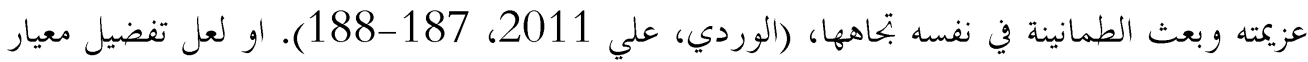

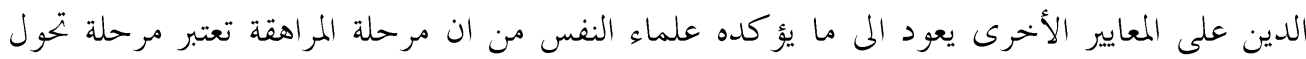

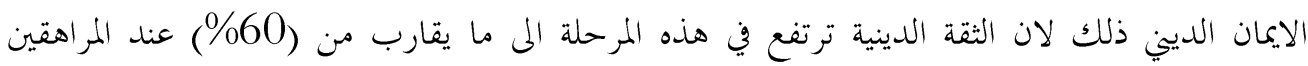
الذكور و(65\%) عند المراهقات الاناث، ولذلك تسمى مرحلة المراهقة بمرحلة اليقضة الدينية (السيد،

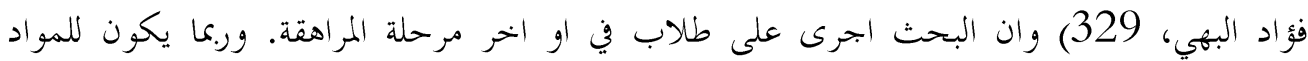
التربوية والتعليمية في المراحل الدراسية السابقة الابتدائية والثانوية كمواد التربية الإسلامية والتاريخ والادب وما تضمنته من قيم دينية وقصص وسير للكثير من الرجال والنساء المؤمنين والمؤمنات دور في تئية تكوين ابتحاه لدى الطلاب لتفضيل ذات الدين في الاختيار الزواجي.

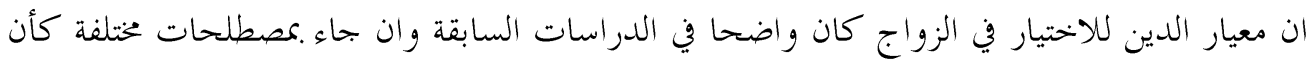

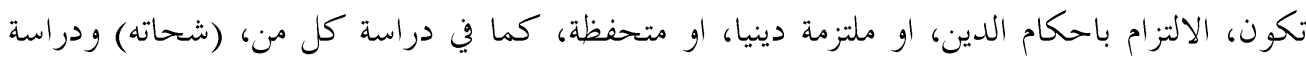
(عطيات ابو العينين)، ودراسة (بوهدا وتايمان).

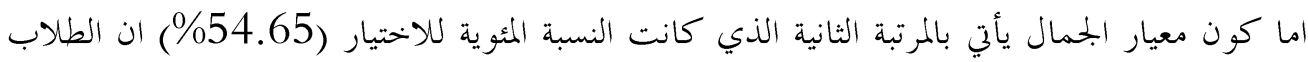
في مثل أعمارهم في هاية المراهقة وبداية الرشد، مرحلة شباب طموح فلابد ان يكون للجمال دور كبير 
ودافع قوي وفعال لتفضيل الجمال، فهو مثلا يحرص ان يختار اجمل الأشياء التي يكتاجها وان كانت كماليات من ملابس واحذية وعطور وهاتف وغيرها بلدقة بكيث تعجبه وتعجب الاخرين، فكيف سيكون حرصه في الاختيار للزوجة التي سترافقه طيلة حياته !؟ حتما سيبحث عن الجمال قصارى جهله وتتفق دراستنا مع ما جاء ببعض الدراسات السابقة الى ان الجمال كان من المعايير الأساسية لاختيار شريك الحياة، كما في دراسة (Buss) ودراسة (بلهدا وتايمان)، ودراسة (ماليكي) ودراسة (شانج) ودراسة (ماير)، ودراسة (القيسي، ماجد). اما معيار الحسب الني كان موضع اهتمام الطلاب للاختيار في الزواج و كانت مرتبته الثالثة بنسبة (51.93\%) كان العربي ولا زال يعتز بحسبه ونسبه ويفتخر والدليل على ذلك الفت كتبا كثيرة في انساب العرب، ونضمت القصائد الشعرية للافتخار بالانساب وليس غريبا اذن ان يأتي ترتيبه الثالث، ور.ما يكون للتعصب القبلي دور في هذا الاختيار ضمن العادات والتقاليد ومن الامثال الشائعة ان (بنت العم لابن العم) و(بنات القبيلة لابنائها) للحفاظ على الحسب والنسب والثروة و التماسك القبلي، فيذكر الدكتور (الوردي) انه من الشائع في زواج المراة في ريف العراق: (ان الحق الأول في زواج المراة الريفية هو اها لابن عمها، فهو يتزوجها بغير مهر او .كهر رمزي، و اذا أراد رجل غريب الزواج بها وجب عليه ترضية ابن عمها بمبلغ من المال يدفعه له. (الوردي، 2011، 177) وحتى وان خف هذا الامر لكننا نعتقد لازالت اثاره راسخة في اذهان الأجيال و لا تزال بعض الاسر متمسكة بهذا العادات للحفاظ على الاحساب و الانساب. اما معيار المال للزواج الذي جاء بالمرتبة الرابعة والأخيرة، فبالرغم من ان الكثير من الناس يطلقون على هذا العصر (بعصر المادة) الا ان ما يبدوا على طلاب الكلية ينظرون الى المال في موضع الاختيار في الزواج ليس بالاهمية التي توازي المعايير الثلاثة الأخرى ور.ما يعود ذلك الى اهم يعتبرون الاعتياث على مال الزوجة نقيصة في حقهم وعيب عليهم لذلك فهو يانف الاعتماد على مال زوجته. وبهذه النتائج يتحقق لنا الهدف الأول وهو التعرف على ترتيب معايير الاختيار في الزواج لطلاب كلية المعارف الذكور حسب أولوياتا و تفضيلها واهميتها لهم في ضوء الحلديث النبوي الشريف، واجبنا على سؤال الفرضية الأولى وهو: ماهو ترتيب الأفضلية لمعايير الاختيار في الزواج التي وردت في الحلديث النبوي الشريف للى العينة الكلية للطلبة الذكور في كلية المعارف الجامعة. 


\section{ثانيا: نتائج البحث حسب الأقسام وتخصصاقا:}

من اجل تحقيق الهدف الثاني والفرضية الثانية للبحث، تم استخراج النسبة المئوية لكل معيار من المعايير الأربعة في كل قسم من الأقسام فكانت النتائج كما في الجحداول والرسوم البيانية التالية.

\section{1 - نتائج معيار الجمال للاقسام:}

بعد ان تم تفريغ بينات معيار الجمال وتبويبها وفقا لاقسام الكلية فكانت النتائج كما في الجلدول رقم (4) والرسم البياني رقم (1) التاليين.

رسم بياني رقم (1) يوضح النسب المئوية لاختيار معيار الجمال حسب اقسام الكلية وتخصصها

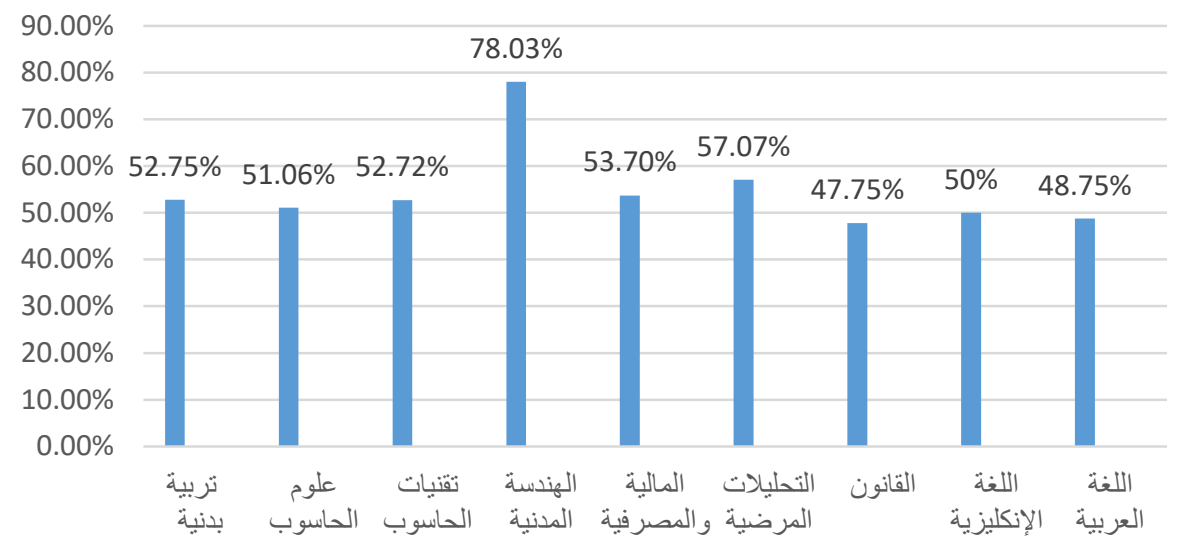

جدول رقم (4) يبين النسب المثوية لاختيار معيار الجمال لاقسام الكلية حسب تخصصها

\begin{tabular}{|c|c|c|c|c|c|c|c|c|}
\hline تربية بدنية & علوم & تلقنيات & المندنية & والمالية & المرضية التحليات & القانون & اللغة الإنكليز ية & اللعر \\
\hline 52.75 & 51.06 & 52.71 & 78.03 & 53.70 & 57.07 & 47.75 & 50.00 & 48.75 \\
\hline$\%$ & $\%$ & $\%$ & $\%$ & $\%$ & $\%$ & $\%$ & $\%$ & $\%$ \\
\hline
\end{tabular}

يبين لنا الجدول رقم (4) والرسم البياني رقم (1) اللذان يوضحان النسب المئوية لاختيار معيار الجمال

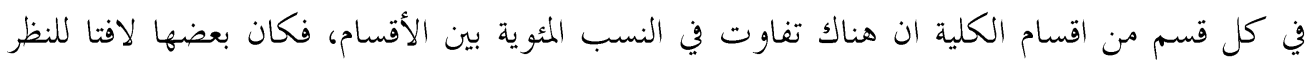
فلقد كان اعلى الأقسام قسم الهندسة المدنية الذي كانت النسبة المئوية لاختيار الطلبة لمعيار الجمال (78.03\%) اذ كان الفرق بينه وبين قسم القانون (31\%) الذي هو اقل الأقسام والذي كانت نسبته (47.75\%) ولعل هذا يعود الى ان الهندسة علم وفن وذوق، وطلابه ذووا خيال واسع فهم يطلبون الجمال في مختلف جوانب الحياة فانعكس التخصص الدراسي على اختيار الجمال بنسبة واضحة جلية. 
ويلي قسم الهندسة المدنية قسم التحليلات المرضية الذي بلغت نسبة اختيار الجمال فيه (57.07\%)، يليه قسم المالية والمصرفية (53.70\%)، فقسم التربية البدنية (52.75\%) ثم يليه قسم تقنيات الحاسوب (52.71\%)، يأتي بعده قسم علوم الحاسوب (51.06\%) فيليه قسم اللغة الإنكليزية

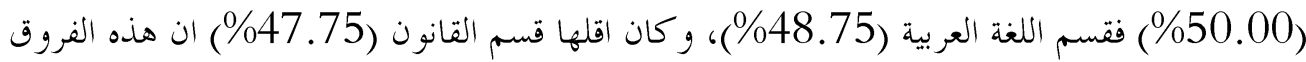
ربما تدلل على وجود علاقة بين التخصص الدراسي والاختيار الزواجي وبذه النتائج يتحقق لنا الهدف الثاني لمعيار الجمال الذي كان يروم التعرف على ترتيب معايير الاختيار في الزواج تبعا لمتغير التخصص الدراسي لاقسام الكلية والاجابة عن الفرض الثاني (هل توجد فروق في ترتيب الأفضلية لمعايير الاختيار الزواجي التي جاءت في الحديث النبوي الشريف تبعا لمتغير التخصص الدراسي في اقسام الكلية التسعة؟) وبهذا تؤكد الدراسة عن وجود فروق متفاوته بين الأقسام ولعل هذا يدفعنا للقول بوجوب دراسة العو امل التي أدت الم هذه الفروق دراسة متعمقة. 2- نتائج معيار المال حسب اقسام الكلية وتخصصاقا: تم تفريغ بيانات معيار المال وتبويبها وفقا لاقسام الكلية فكانت النتائج كما في الجمدول رقم (5) والرسم

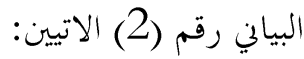

رسم بياني رقم (2) يوضح النسب المئوية لاختيار معيار المال حسب اقسام الكلية وتخصصاتا

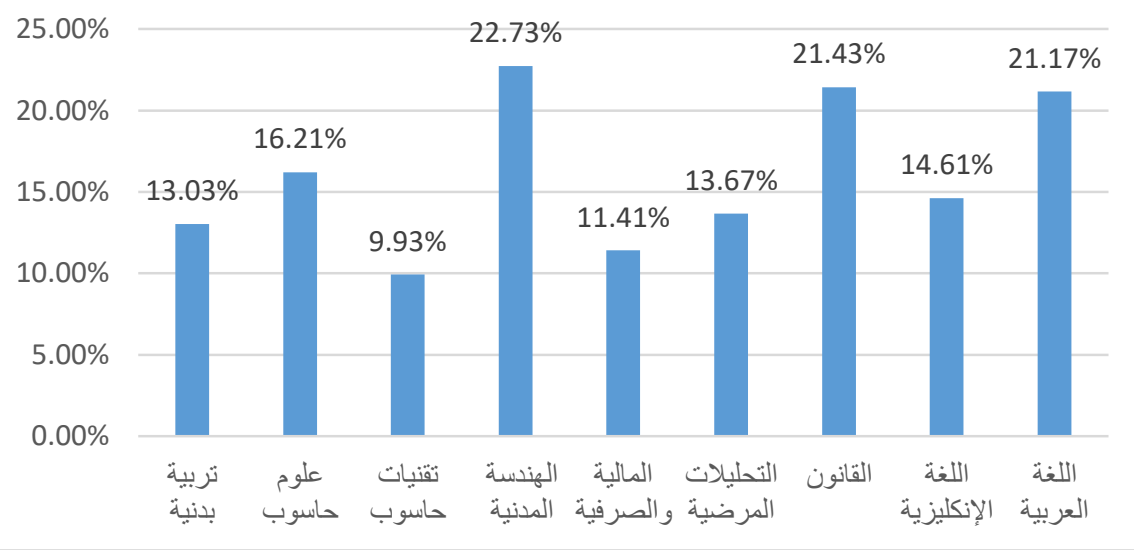

جدول رقم (5) ييين النسب المئوية لاختيار معيار المال لاقسام الكلية حسب تخصصاتًا

\begin{tabular}{|c|c|c|c|c|c|c|c|c|}
\hline تربية بدنية & علحماسوب & تلحنيات & الملدنية & والمالية & المرضية & القانون & الإلغكليز & اللغة العر بية \\
\hline$\% 13.03$ & $\% 16.21$ & $\% 9.93$ & $\% 22.73$ & \%11.41 & $\% 13.67$ & $\% 21.43$ & $\% 14.61$ & $\% 21.17$ \\
\hline
\end{tabular}


بالرغم من ان معيار المال كان منخفضا كثيرا عن المعايير الثلاثة الأخرى في العينة الكلية، وعند التدقيق في الجدول رقم (5) والرسم البياني له رقم (2) السابقين بنحد ان هناك تفاوت وفرق في النسب المئوية

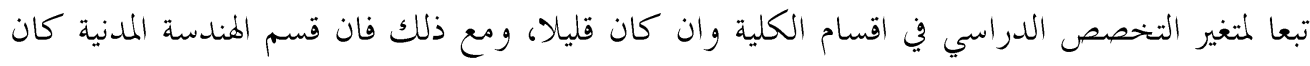
اعلى الأقسام اذ بلغت النسبة المئوية لاختيار طلابه لمعيار المال وتفضيله على المعايير الأخرى

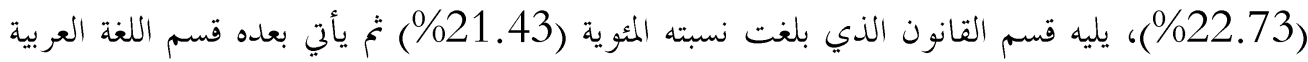

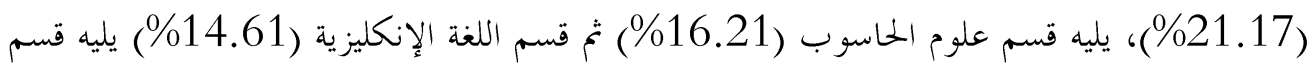

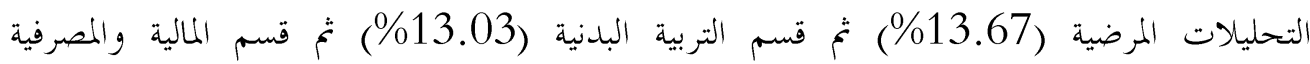
(11.41\%) و كان اقلها قسم تقنيات الحاسوب (19.93\%)، وهكذا بحد ان الفروق بين الأقسام لمعيار

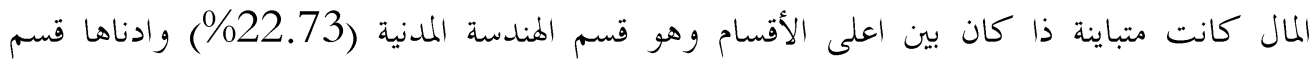
تقنيات الحاسوب (939\%) كان (13\%) تقريبا اما الفروق بين الأقسام الأخرى فتراوحت ما بـ بين (1-10\%)، وهذا يعني ان نظرة الطلاب الم المال وابتحههم نهوه كمعيار للاختيار الزواجي متباينة. وبهذا يتحقق لنا بيان الهدف الثاني الذي كنا نود تحقيقه وهو: التعرف على ترتيب معايير الاختيار في

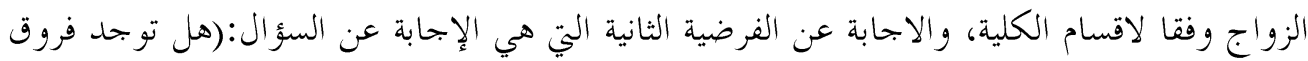
في ترتيب معايير الاختيار في الزواج التي جاءت في الحديث النبوي الشريف تبعا لمتغير التخصص الدراسي في اقسام الكلية؟ وهذه النتائج تبين الدراسة عن وجود فروق متباينة لمعيار المال بين اقسام الكلية.

\section{3- نتائج معيار الحسب في اقسام الكلية وفقا لتخصصاتحا:}

بعد ان تم تفريغ البيانات وتبو يبها في الجدول رقم (6) وقمنا باجرء الرسم البياني رقم (3) تبين لنا الاتي:

$$
\text { رسم بياني رقم (3) يوضح النسب المئوية لاختيار معيار الحسب وفقا لمتغير اقسام الكلية وتخصصاها }
$$

\begin{tabular}{|c|c|c|c|c|c|c|c|c|c|}
\hline $70.00 \%$ & \multicolumn{3}{|c|}{$60.46 \%$} & & $59.87 \%$ & \multicolumn{4}{|c|}{$54.92 \% \quad 55.98 \%$} \\
\hline $60.00 \%$ & $48.73 \%$ & & $50.42 \%$ & $1420 \%$ & & $47.65 \%$ & & & $44.95 \%$ \\
\hline $40.00 \%$ & & & & & & & & & \\
\hline $30.00 \%$ & & & & & & & & & \\
\hline $20.00 \%$ & & & & & & & & & \\
\hline \multirow{3}{*}{$\begin{array}{r}10.00 \% \\
0.00 \%\end{array}$} & & & & & & & & & \\
\hline & & & & & & & & & \\
\hline & بدنية & حاسوب & تقنيات & الهندسة & و المصر فية & التحليلات & القانون & الانكليز ية & العر بية \\
\hline
\end{tabular}


جدول رقم (6) يبين النسب المثوية لاختيار معيار الحسب لاقسام الكلية حسب تخصصاتًا

\begin{tabular}{|c|c|c|c|c|c|c|c|c|}
\hline تربية بدنية & علوم & تقنيات & المندنية & والمالية & التحرليلات & القانون & الإلغنة الإنيزية & العر العة \\
\hline 48.73 & 60.46 & 50.42 & 44.39 & 59.87 & 47.65 & 54.92 & 55.98 & 44.95 \\
\hline$\%$ & $\%$ & $\%$ & $\%$ & $\%$ & $\%$ & $\%$ & $\%$ & $\%$ \\
\hline
\end{tabular}

يبين لنا الجحدول رقم (6) والرسم البياني له رقم (3) ان اعلى الأقسام في النسبة المئوية لاختيار معيار الحسب وتفضيله على المعايير الأخرى كان قسم علوم الحاسوب اذ بلغت النسبة المئوية (46.46\%) ثمع يليه قسم المالية المصرفية الذي كانت النسبة المئوية فيه (59.87\%) يليه قسم اللغة الإنكليزية الذي بلغت النسبة المئوية فيه (95.98\%)، و يأتي بعده قسم القانون (54.92\%) ثم قسم تقنيات الحاسوب (50.42\%) يليه قسم التربية البدنية حيث كانت النسبة المئوية له (48.73\%) يليه قسم التحليلات المرضية بنسبة (65.65\%)، يليه قسم اللغة العربية (44.95\%) بينما كان اقلها قسم الهندسة المدنية بنسبه (44.39\%) تكشف لنا هذه النتائج عن وجود فروق في النسب المئوية لاختيار الطلاب لمعيار الحسب تبعا للتخصصات الدراسية فكان الفرق بين اعلى نسبة في الأقسام وهو قسم علوم الحاسوب (60.46\%) وادلن الأقسام في النسبة المئوية لتفضل الحسب كان قسم الهندسة المدنية الذي بلغت نسبته (44.39\%) اذ كان الفرق (16\%) بينما الفروق بين الأقسام بعضها بعضا فتراوحت مابين (1\%-10\%) تقريبا. وبهذه النتائج يتحقق لنا جانب اخر من الهدف الثاني والذي هو التعرف على ترتيب معايير الاختيار في الزواج لمعيار الحسب تبعا للتخصصات الدراسية في اقسام الكلية، وبتجبب النتائج عن سؤال الفرض الثاني القائل: (هل توجد فروق في ترتيب معايير الاختيار في الزواج التي جاءت في الحديث النبوي الشريف تبعا لمتغير التخصص الدراسي لاقسام الكلية) فقد اثبتت الدراسة عن وجود فروق في النسبه المئوية لاختيار معيار الحسب تبعا لاختلاف التخصص الدراسي لاقسام الكلية

\section{4- نتائج معيار الدين في اقسام الكلية وفقا لتخصصاقا}

افرغنا البيانات وبو بناها كما في الجلدول رقم (7) والرسم البياني رقم (4) الاتيين فكانت النتائج:

جدول رقم (7) يبين النسب المثوية لاختيار معيار الدين لاقسام الكلية حسب تخصصاها

\begin{tabular}{|c|c|c|c|c|c|c|c|c|}
\hline تربية بدنية & علوم & تقنيات & المندسة & والمالية & المرضحليات & القانون & اللغإنكليز ية & اللعر بية \\
\hline$\% 78.27$ & $\% 63.42$ & $\% 80.42$ & $\% 53.34$ & $\% 61.85$ & $\% 78.40$ & $\% 66.50$ & $\% 87.57$ & $\% 64.5$ \\
\hline
\end{tabular}


رسم بياني رقم (4) ويضح النسب المئوية لاختيار معيار الدين حسب اقسام الكلية وتخصصاها

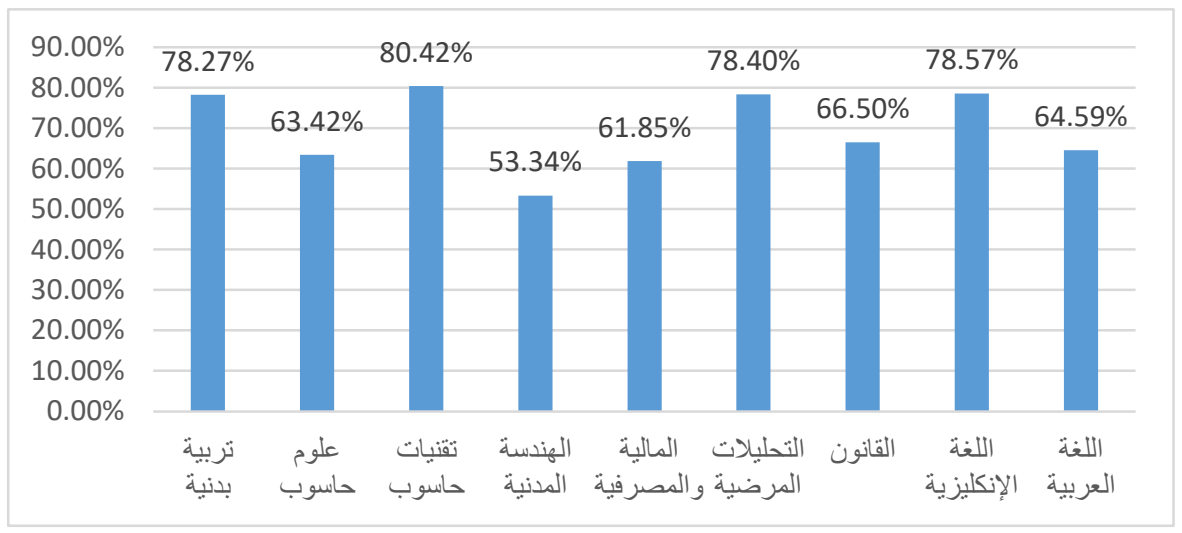

الجحدول السابق رقم (7) والرسم البياني له رقم (4) عن وجود فروق واضحة في النسب المئوية لاختيار

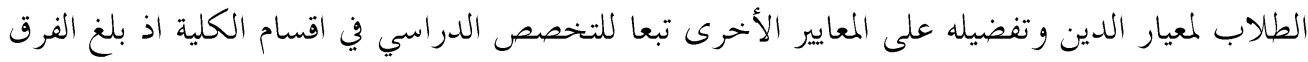

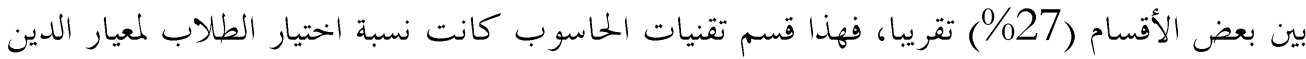
اعلى الأقسام فبلغت (80.42\%) بينما كان طلاب قسم المندسة المدنية ادنى الأقسام فبلغت النسبة المئوية (53.34\%)، اما الذي يلي قسم تقنيات الحاسوب فكان قسم اللغة الإنكليزية اذ كانت النسبة

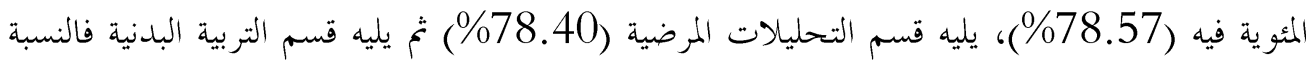

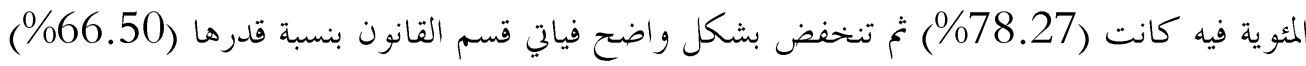

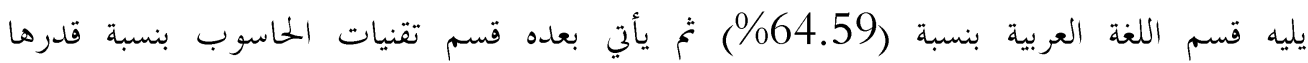

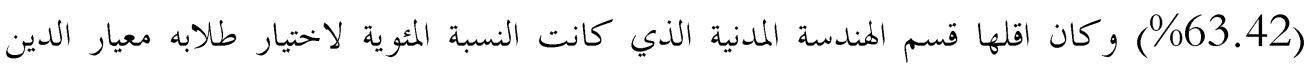
و تفضيله على المعايير الأخرى (53.34\%) و هذذه النتائج نكون قد حققنا هدفنا الثاني وفرضيته. وهكذا يتحقق لنا الهدف حيث كشفت لنا الجمداول السابقة والرسوم البيانية ان المعايير الأربعة التي وردت في الحديث النبوي الشريف تباينت في ترتيبها تبعا لمتغير الأقسام وتخصصاها، وكان الفرق واضحا بين اغلب الأقسام، بينما كان قليلا بين بعضها الاخر.

\section{ثالثا: النتائج حسب المراحل الدراسية:}

من اجل تحقيق الهدف الثالث والفرضية الثالثة للبحث تم استخراج النسب المئوية لكل معيار من معايير

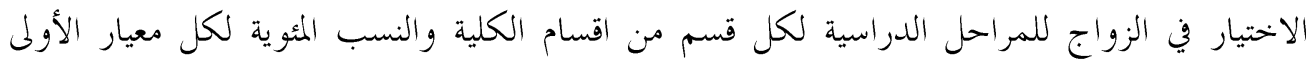
و الثالثة للاقسام كافة فكانت النتائج كما في الجداول و الرسوم البيانية التالية: 


\section{أ- نتائج معايير الاختيار في الزواج للمراحل الدراسية لكافة الأقسام}

عند استخراج النسبة المئوية للمعايير في كافة الأقسام، ثم تم استخراج المتوسط الحسابي للنسب المئوية للاقسام بحتمعة فكانت النتائج كما مبين في الجحدول رقم (8) والرسم البياني رقم (5) التاليين: جدول رقم (8) ييين النسب المئوية لمعايير الاختيار في الزواج حسب المراحل الدراسية

\begin{tabular}{|c|c|c|c|c|c|c|c|c|c|}
\hline \multicolumn{2}{|r|}{ الدين\% } & \multicolumn{2}{|r|}{ الحسب\%\% } & \multicolumn{2}{|r|}{ \%المال } & \multicolumn{2}{|c|}{ \% الجمال } & & \multirow{4}{*}{ ت } \\
\hline المرحلة & المرحلة & المرحلة & المرحلة & المرحلة & المرحلة & المرحلة & المرحلة & & \\
\hline الثالثة & الأولى & الثالثة & الأولى & الثالثة & الأولى & الثالثة & لالأولى & & \\
\hline$\%$ & $\%$ & $\%$ & $\%$ & $\%$ & $\%$ & $\%$ & $\%$ & & \\
\hline 62.50 & 66.67 & 33.33 & 56.57 & 12.33 & 30.00 & 54.17 & 43.33 & اللغة العربية & 1 \\
\hline 73.80 & 83.33 & 59.52 & 52.44 & 12.07 & 17.14 & 54.76 & 45.24 & اللغة الإنكليزية & 2 \\
\hline 73.01 & 59.99 & 58.33 & 51.11 & 20.63 & 22.22 & 46.61 & 48.89 & القانون & 3 \\
\hline 85.96 & 70.83 & 47.37 & 47.92 & 8.77 & 18.57 & 57.89 & 56.25 & التحليلات المرضية & 4 \\
\hline 76.19 & 47.50 & 63.49 & 56.25 & 6.15 & 16.67 & 53.97 & 53.42 & المالية والمصرفية & 5 \\
\hline 40.00 & 66.67 & 43.33 & 45.45 & 33.33 & 12.12 & 83.33 & 72.73 & الهندسة المدنية & 6 \\
\hline 87.50 & 73.33 & 54.16 & 46.67 & 2.08 & 17.78 & 52.09 & 53.33 & تقنيات الحاسوب & 7 \\
\hline 63.33 & 63.91 & 63.33 & 57.58 & 23.33 & 9.09 & 56.67 & 45.45 & علوم ا- & 8 \\
\hline 83.73 & 73.26 & 35.29 & 62.16 & 21.57 & 4.48 & 58.83 & 46.67 & التربية المدنية & 9 \\
\hline 71.73 & 67.28 & 50.95 & 52.91 & 15.58 & 16.47 & 57.59 & 51.70 & للمنب المثئوسية الحسابي & \\
\hline
\end{tabular}

$$
\text { رسم بياني رقم (6) يوضح النسب المثوية لمعايير الاختيار في الزواج للمراحل الدراسية }
$$

\section{$80.00 \%$ \\ $60.00 \%$ \\ $40.00 \%$ \\ $20.00 \%$ \\ $0.00 \%$} $67.28 \%$
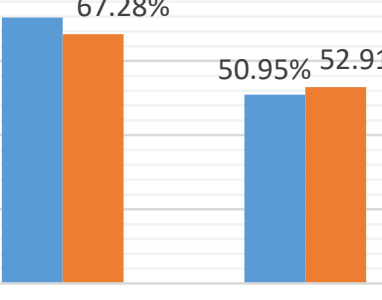

$15.58 \% 16.47 \%$

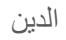

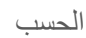

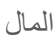

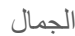


بين الجدول رقم (8) والرسم البياني له رقم (5) ولمعايير الاختيار والزواجي الأربعة وفقا للمراحل الدراسية لكافة الأقسام كما يأتي:

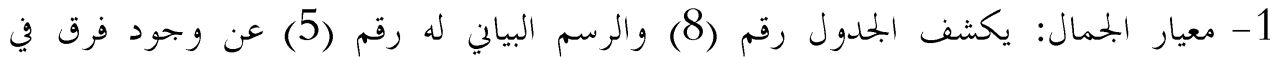
المتوسطات الحسابية بين المرحلتين الدراستين الأولى والثالثة اذ ان المتوسط الحسابي للنسبة المئوية لاختيار الجمال في المرحلة الثالثة لكافة الأقسام اعلى من المتوسط الحسابي للنسبة المئوية للمراحل الأولى بنسبة قدرها (6\%) حيث ان المتوسط الحسابي للنسبة المئوية في المرحلة الثالثة كانت

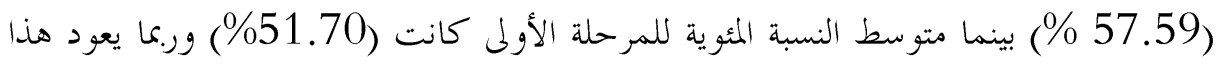
التطور الضج العقلي والوجداني العاطفي والاجتماعي للطلبة او لربما ان طلاب المرحلة الثالثة اصبحوا اقرب زمانا الى قرار الاختيار الزواجي لافهم على ابوب التخرج ولربما من بعد التخرج يأتي قرار الزواج. 2- معيار المال: يبين الجحدول رقم (8) والرسم البياني رقم (5) ان الفرق بين المتوسط الحسابين

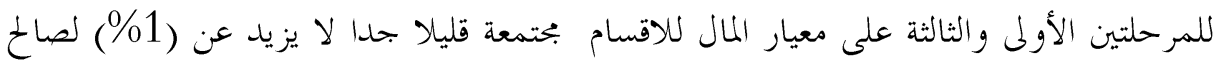

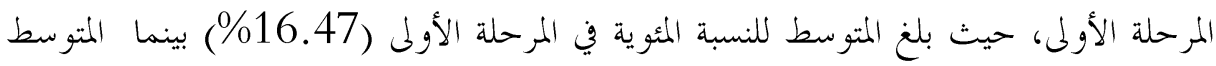
الحسابي للمرحلة الثالثة كان (15.48\%) 3- معيار الحسب: يوضع الجدول رقم (8) والرسم البياني رقم (5) ان المتوسط الحسابي للنسبة

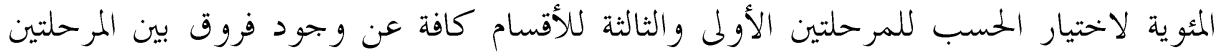
مقداره (2\%) لصالح المرحلة الأولى اذ بلغ متوسط النسبة المئوية لاختيار الحسب من قبل المرحلة

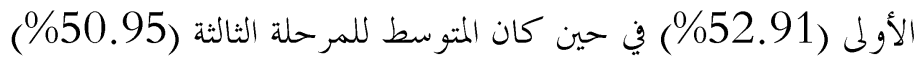
4- معيار الدين: يكشف لنا الجلدول رقم (8) والرسم ابياني له رقم (5) ان المتوسط الحسابي للنسبة المئوية لاختيار الدين للمرحلتين الاولى والثالثة للاقسام بحتمعة عن وجود فرق رقبم بين المرحلتين

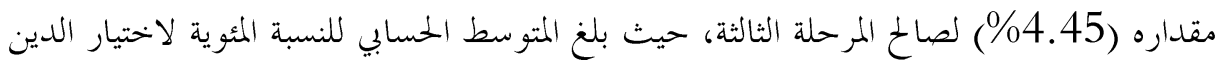

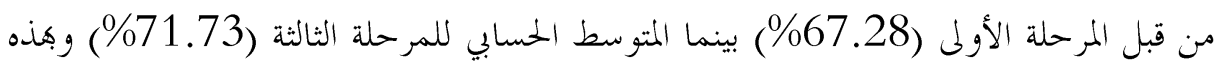
النتائج نستطيع القول عن وجود فروق بين المراحل الدراسية في معايير الاختيار الزواجي بدرجات متفاوتة، تارة لصالح المرحلة الأولى، وتارة أخرى لصالح المرحلة الثالثة وقد تحقق جزء لمريك من الهدف الثالث والفرضية الثالثة 


\section{ب-نتائج معايير الاختيار في الزواج الأربعة (كل معيار على حدة تبعا للمراحل الدراسية في (اقسام الكلية)}

1- معيار الجمال للمراحل الدراسية في كل قسم من اقسام الكلية بعد ان تم استخراج النسب المئوية لمعيار الجمال لكل قسم من اقسام الكلية كانت النتائج كما في الجدول رقم (9) والرسم البياني رقم (6) التاليين: جدول رقم (9) يبين النسب المئوية لمعيار الجمال للمراحل الدراسية لكل قسم

\begin{tabular}{|c|c|c|c|c|c|c|c|c|c|}
\hline تربية & 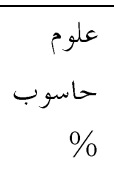 & تقنيات & هندسة & ومالية & $\begin{array}{r}\text { التحليلات } \\
\text { المرضية } \\
\%\end{array}$ & القانون & $\begin{array}{r}\text { اللغة } \\
\text { الإنكليز ية } \\
\%\end{array}$ & $\begin{array}{r}\text { اللغر بية } \\
\text { العر }\end{array}$ & \\
\hline 46.67 & 45.45 & 53.33 & 72.73 & 53.42 & 56.25 & 48.89 & 45.24 & 43.33 & المرحلة الأولى \\
\hline 58.83 & 56.67 & 52.09 & 83.33 & 53.97 & 57.89 & 46.61 & 54.76 & 54.17 & المرحلة الثالثة \\
\hline
\end{tabular}

رسم بياني رقم (7) يوضح النسبة المئوية لمعيار الجمال للمراحل الدراسية في كل قسم من اقسام الكلية

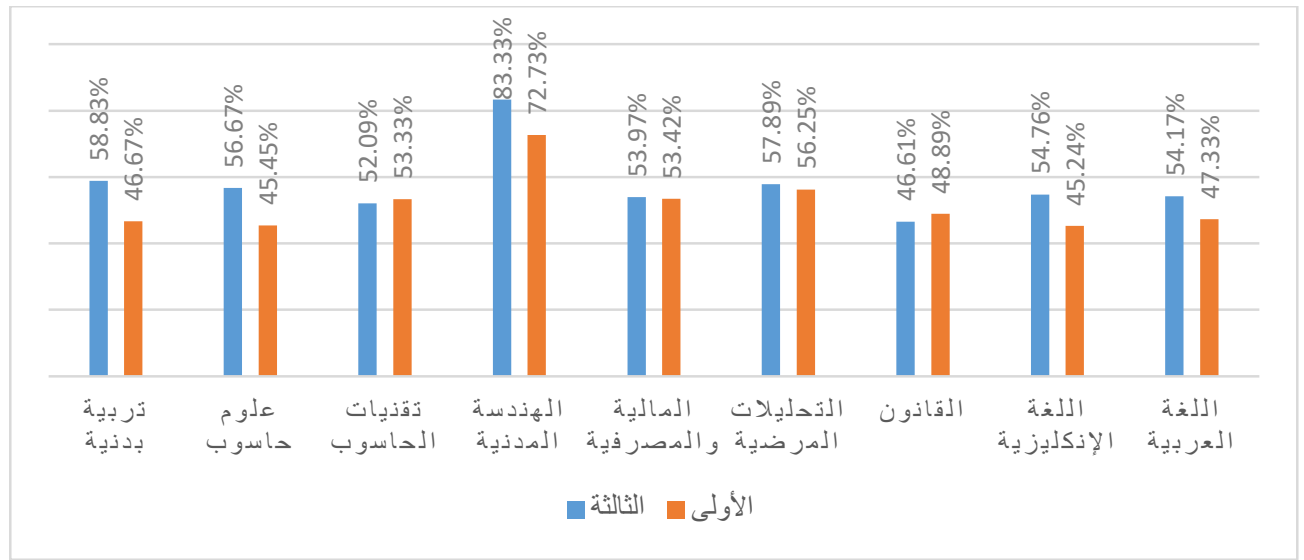

يوضع الجحدول السابق رقم (9) والرسم البياني له رقم (6) ان الفرق في النسبة المئوية بين المرحلتين (الأولى والثالثة) في كل قسم من اقسام الكلية اكثر وضوحا اذ ان النسبة المئوية لمعيار الجمال في المرحلة الثالثة في اغلب القسام كانت اعلى منها في المراحل الأولى، حيث كانت في المرحلة الثرام الثالثة لقسم التربية الرياضة (58.83\%) بينما في المرحلة الأولى (46.67\%) بفارق (12.16\%) لصالح المرحلة الثالثة، يليها في قسم علوم الحاسوب كان الفرق (11.22\%) لصالح المرحلة الثالثة، يليها قسم اللغة العربية بفارق قدرة (10.84\%) يليه قسم الهندسة المدنية بفارق (10.6\%) يليه قسم اللغة الإنكليزية بفارق قدره (9.52\%)، اما ما تبقى من اقسام فكانت النسبة المئوية لاختيار الجمال للمرحلة الأولى لقسم 
القانون اعلى من المرحلة الثالثة فكان الفرق قليلا قدره (2.28\%) لصالح المرحلة الأولى، ثم قسم تقنيات الحاسوب بفارق قدره (1.42\%) وهذه النتائج يتحقق جزء اخر من الهدف الثنالث الفرضية الثالثة وهو الكشف عن الفروق بين المراحل الدراسية لمعيار الجمال في الاقسام. 2- معيار المال للمر احل الدراسية في كل قسم من اقسام الكلية ولما تم استخر اج النسب المئوية لمعيار المال لكل قسم من اقسام الكلية كانت النتائج كما في الجلدول رقم (10) والرسم البياني رقم (7) رسم البياني رقم (7) يوضح النسب المثوية لمعيار المال للمراحل الدراسية في كل قسم من اقسام الكلية

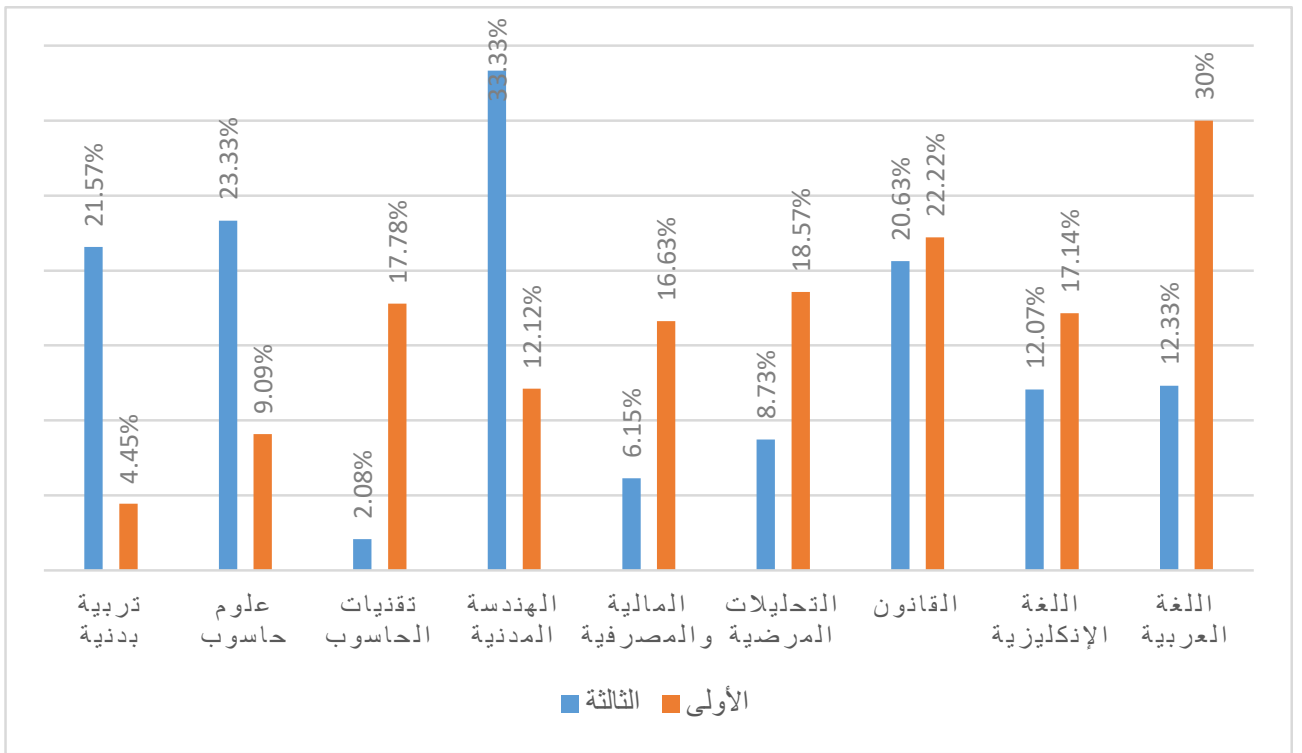

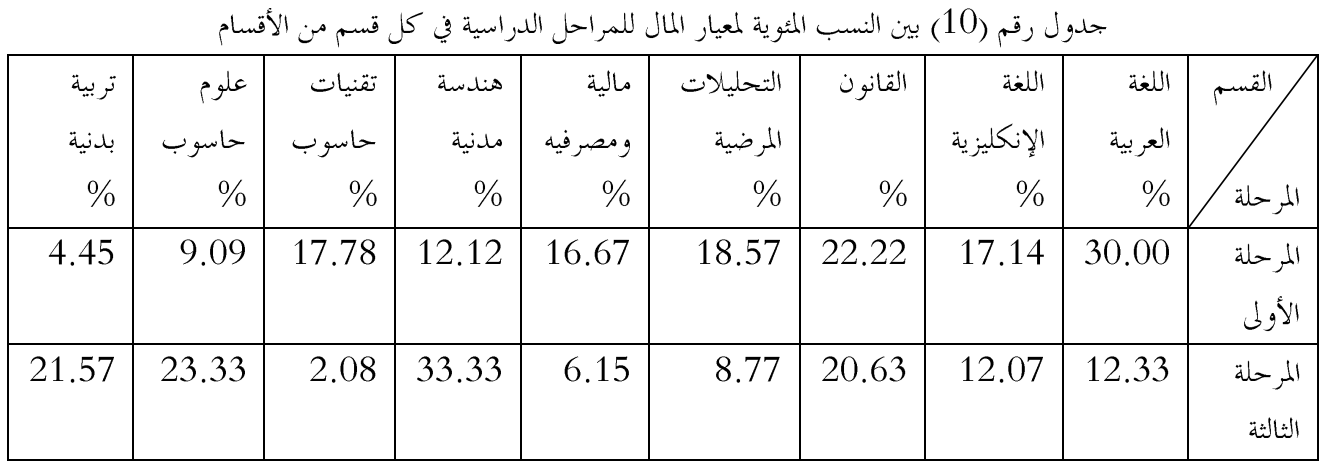


يكشف لنا الجداول رقم (10) والرسم البياني رقم (7) عن وجود فروق واضحة في النسبة المئوية لاختيار المال تبعا للمراحل الدراسية اذ ان اغلب الأقسام كانت النسبة المئوية للمراحل الأولى اعلى فئل منها في المرحلة الثالثة، وهي اقسام اللغة العربية كان الفرق (17.67\%) لصالح المرحلة الأولى، يليه قسم تقنيات الحاسوب كان الفرق (15.7\%) لصالح المرحلة الأولى، يليه قسم المالية والمصرفية بفارق قدره (10.48\%)، ثم يليه قسم التحليلات المرضية بفارق قدره (9.8) ثم قسم اللغة الإنكليزية بفارق قدره

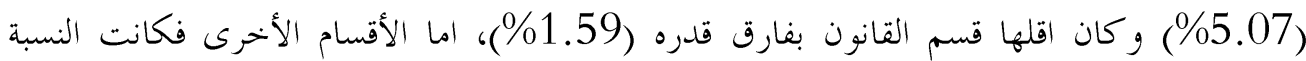
المئوية للمرحلة الثالثة اعلى بدرجة واضحة عن النسبة المئوية للمرحلة الأولى وهي: قسم الهندسة المدنية

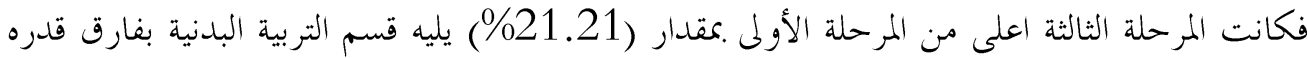

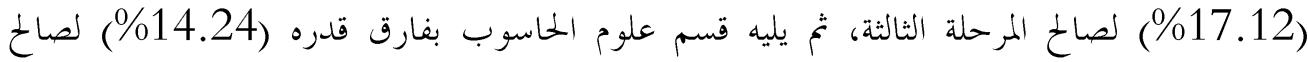
المرحلة الثالثة. وبهذه النتائج تنكشف لنا الفروق الموجودة بين المراحل الدراسية لمعيار المال وفي الغالب كان لصالح

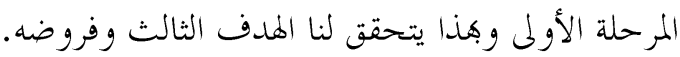
3- معيار الحسب للمراحل الدراسية لكل قسم من اقسام الكلية تكشف لنا النسب المئوية لمعيار الحسب في كل قسم من اقسام النتائج كما في الجحدول رقم (11) والرسم البيالي رقم (8) التاليين: رسم البياني رقم (8) يوضح النسب المثوية لمعيار الحسب للمراحل الدراسية في كل قسم من اقسام الكلية

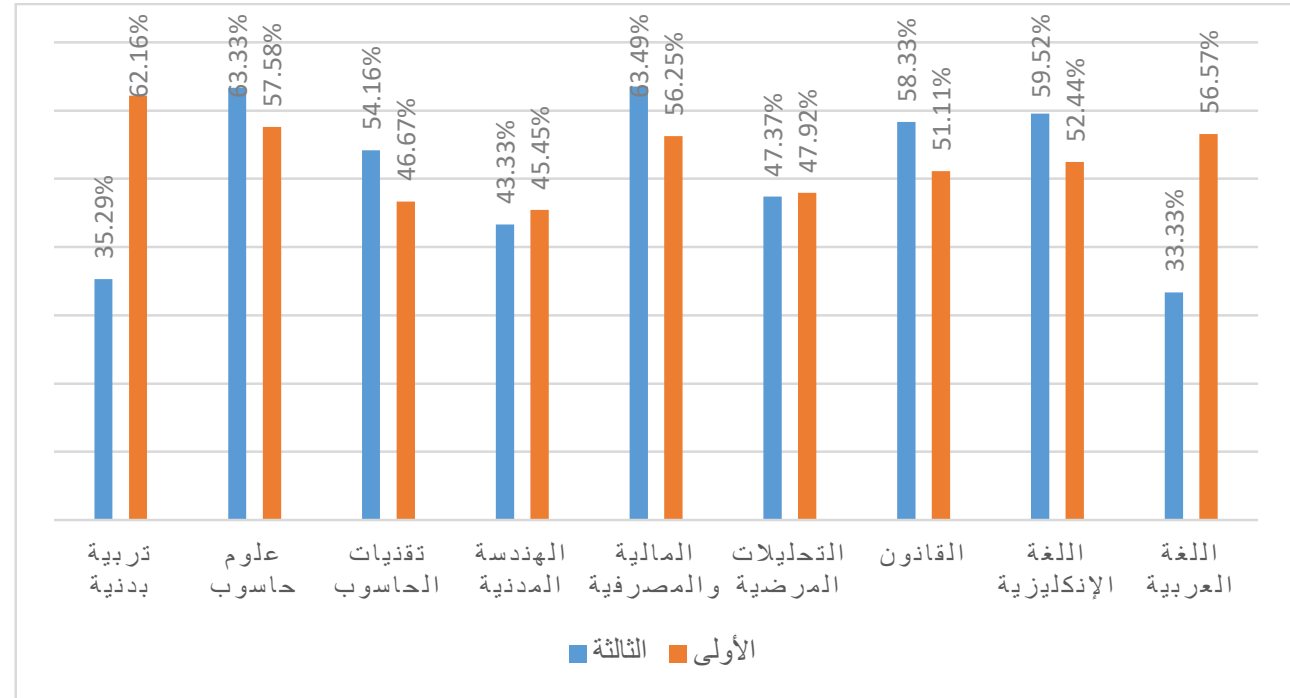




\begin{tabular}{|c|c|c|c|c|c|c|c|c|c|}
\hline تربية & علوم & تقنيات & هندسة & مالية & التحليلات & القانون & اللغة & اللغة & لق \\
\hline بلدنية & حاسوب & حاسوب & مدنية & ومصرفيه & المرضية & & الإنكليز ية & العربية & \\
\hline$\%$ & $\%$ & $\%$ & $\%$ & $\%$ & $\%$ & $\%$ & $\%$ & $\%$ & \\
\hline 62.16 & 57.58 & 46.67 & 45.45 & 56.25 & 47.92 & 51.11 & 52.44 & 56.57 & المرحلة \\
\hline 3529 & 6333 & 5416 & 4333 & 6349 & $47 \quad 37$ & 5833 & 5952 & 3333 & \\
\hline & & 34.10 & 45.05 & $0.7 .+7$ & 4.51 & 50.05 & $39 . J 2$ & J5.J5 & الثرالثة \\
\hline
\end{tabular}

يوضع الجحدول رقم (11) والرسم البياني رقم (8) عن وجود فروق بينه في النسب المئوية لاختيار الحسب تبعا للمراحل الدراسية حيث ان بعض الأقسام كانت النسب المئوية للمرحلة الأولى اعلى منها ولها

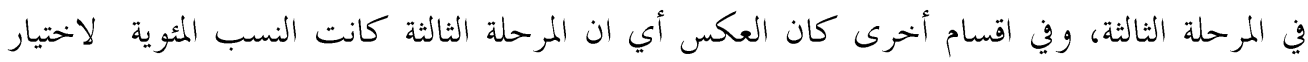

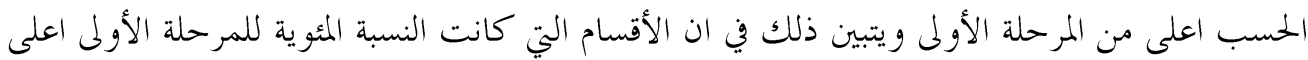
هي قسم التربية البدنية حيث بلغ الفرق (26.91\%) يليه قسم اللغة العربية بفارق قدره (23.24\%)

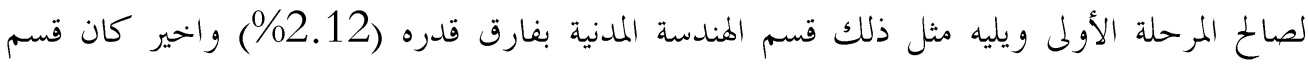
التحليلات المرضية بنسبة قليلة بلغت (0.55\%)، في حين كانت النسبة المئوية في المرحلة الثالثة في الأقسام الأخرى اعلى من المرحلة الأولى بدرجات متقاربة مقدارها (\%) (1\%) تقريبا وهي اقسام تقنيات الحاسوب، فقسم المالية المصرفية، ثم قسم القانون، فقسم اللغة الإنكليزية وأخيرا قسم علوم الحاسوب تهرب . مقدار (15\%).

وهكذا تكشف النتائج عن وجود فروق وتفاوت في النسب المئوية تبعا للمراحل الدراسية ويتم تحقيق الهدف الثالث وفرضياته. 4- معيار الدين للمراحل الدراسية في كل قسم من اقسام الكلية: تبين لنا النسب المئوية لمعيار الدين في كل قسم النتائج كما في الجدول رقم (12) والرسم البياني رقم (9) 
الرسم البياني رقم (9) يبين النسب المئوية لمعيار الدين للمراحل الدراسية لاقسام الكلية

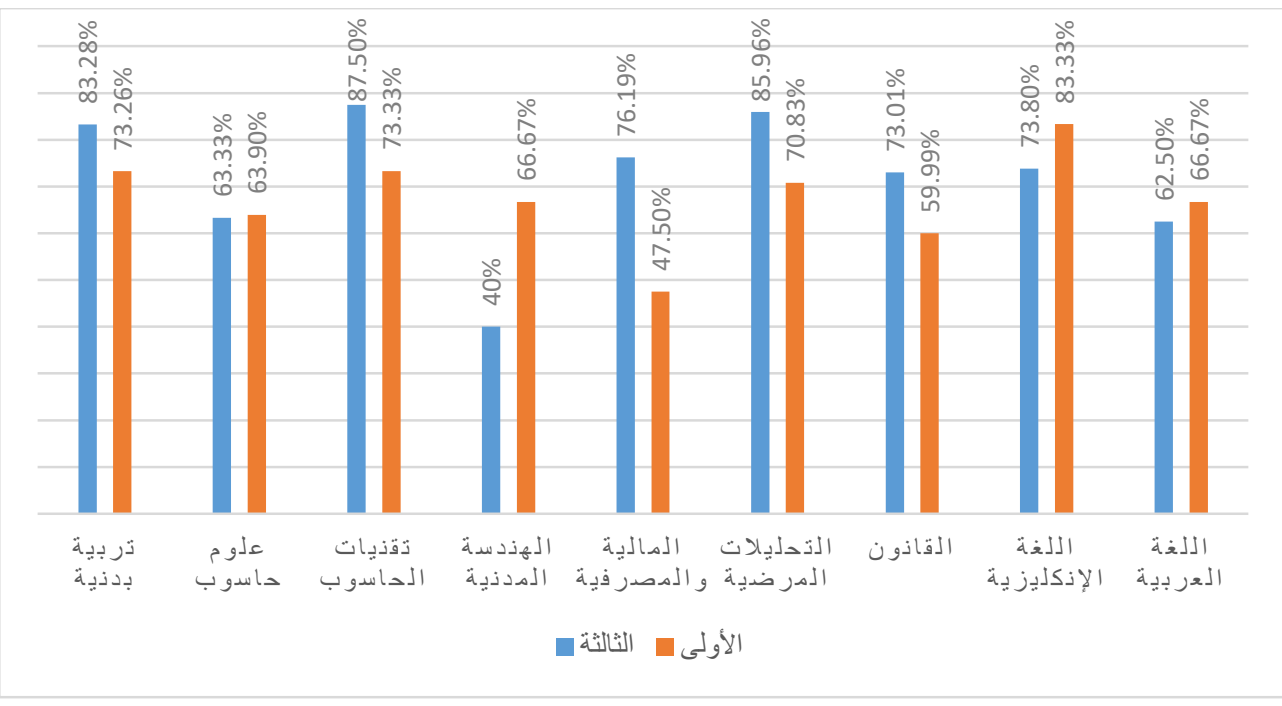

\begin{tabular}{|c|c|c|c|c|c|c|c|c|c|}
\hline تربية & علوم & تقنيات & هندسة & مالية & التحليلات & القانون & اللغة & اللغة & \\
\hline بدنية & حاسوب & حاسوب & مدنية & ومصرفيه & المرضية & & الإنكليزية & العربية & \\
\hline$\%$ & $\%$ & $\%$ & $\%$ & $\%$ & $\%$ & $\%$ & $\%$ & $\%$ & رحلة \\
\hline 73.26 & 63.91 & 73.33 & 66.67 & 47.50 & 70.83 & 59.99 & 83.33 & 66.67 & الأولى الملة \\
\hline 83.28 & 63.33 & 87.50 & 40.00 & 76.19 & 85.96 & 73.01 & 73.80 & 62.50 & المرحلة \\
\hline
\end{tabular}

يبين الجحدول رقم (12) و الرسم البياني له رقم (9) عن وجود فروق واضحة في النسب المئوية لاختيار الدين تبعا للمراحل الدراسية المختلفة في اقسام الكلية، اذ ان بعض الأقسام كانت النسبة المئوية للمرحلة الأولى اعلى من النسبة المئوية في المرحلة الثالثة، وعلى العكس في بعض الأقسام الأخرى حيث كانت النسبة المئوية للاختيار الديني في المرحلة الثالثة اعلى منها في المرحلة الأولى. ووفي ضوء هذه النتائج تبين ان النسبة المئوية للمرحلة الأولى لقسم الهندسة المدنية اعلى من النسبة المئوية للمرحلة الثالثة للقسم معقدار (26.67\%)، تليها المرحلة الأولى لقسم اللغة الإنكليزية اعلى من المرحلة الثالثة بنسبه قدرها (93.53\%) ثم تليها النسبة المئوية للمرحلة الأولى في قسم اللغة العربية، وان اقلها كان للمرحلة الأولى في قسم علوم الحاسوب بلرجة قدرها (0.58\%)، في حين كانت النسبة المئوية لاختيار الدين في 
المرحلة الثالثة اعلى من النسبة المئوية في المرحلة الأولى لقسم المالية المصرفية بمقدار (28.69\%) تليها

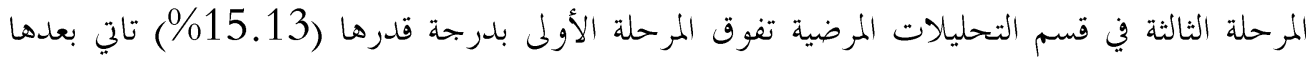
لاختيار الدين في المرحلة الثالثة لقسم تقنيات الحاسوب التي تفوق المرحلة الأولى بنسبة قدرها

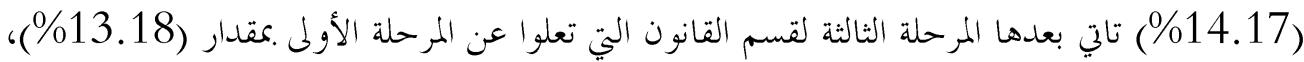

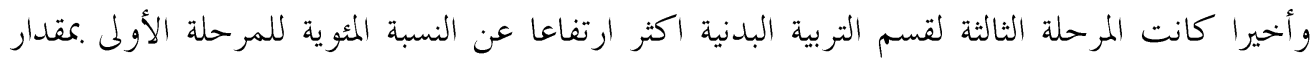
(10.02\%)، وهذا النتائج نستطيع القول عن وجود علاقة بين معيار الدين ومستوى المراحل الدراسية ويتحقق الهدف الثالث وفرضيته.

\section{رابعا: نتائج البحث حسب متغير المستوى الاقتصادي:}

من اجل تحقيق الهدف الرابع، الذي هو التعرف على معايير الاختيار في الزواج التي جاءت في الحلديث النبوي الشريف حسب أولو يتها وتفضيلها وفقا لمتغير المستوى الاقتصادي للطلبة والفرض الرابع للإجابة عن السؤال هل توجد فروق في الأفضلية لمعايير الاختيار تبعا لمتغير المستوى الاقتصادي. قام الباحث بتصنيف استمارات الاسبانه الى بحموعتين لاولى تمثل الطلبة الذين يقل دخلهم الشهري عن مليون دينار عراقي والثانية الطلبة الذين يزيد دخلهم عن مليون دينار عراقي فكانت النتائج كما في لئي

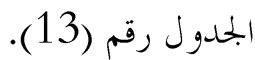

جدول رقم (13) ييين عينه البحث حسب المستوى الاقتصادي

\begin{tabular}{|c|c|c|c|c|c|c|c|}
\hline \multicolumn{3}{|r|}{ المرحلة الثالثة } & \multicolumn{3}{|c|}{ المرحلة الأولى } & \multirow{3}{*}{ الأقسام } & \\
\hline المجموع & اكثر من & اقل من & المجموع ع & اكثر من & اقل من & & ت \\
\hline & مليون & مليون & & مليون & مليون & & \\
\hline 10 & 6 & 4 & 9 & 4 & 5 & اللغة العربية & 1 \\
\hline 14 & 4 & 10 & 14 & 6 & 8 & اللغة الإنكليزية & 2 \\
\hline 21 & 9 & 12 & 19 & 9 & 10 & القانون & 3 \\
\hline 19 & 8 & 11 & 16 & 7 & 9 & تحليلات مرضية & 4 \\
\hline 21 & 11 & 10 & 16 & 5 & 11 & مالية ومصرفية & 5 \\
\hline 10 & 6 & 4 & 11 & 5 & 6 & هندسة مدنية & 6 \\
\hline 16 & 7 & 9 & 15 & 7 & 8 & تقنيات حاسوب & 7 \\
\hline 10 & 4 & 6 & 11 & 4 & 7 & علوم حاسوب & 8 \\
\hline 17 & 7 & 10 & 15 & 6 & 9 & تربية بدنية & 9 \\
\hline 138 & 62 & 76 & 126 & 53 & 73 & المجموع & \\
\hline
\end{tabular}


يبين الجحدول أعلاه رقم (13) ان عدد الطلبة الذين يقل دخلهم عن مليون اكثر من عدد الطلبة الذين يزيد دخلهم عن مليون دينار عراقي بنسبة قليلة.

\section{ت-نتائج المرحلة الأولى حسب المستوى الاقتصادي:}

بعد استخراج النسب المئوية والمتوسط الحسابي لكل معيار من معايير الاختيار في الزواج لعينة طلبة

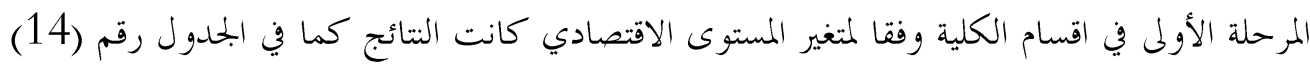
والرسم البياني رقم (10) الاتيين:

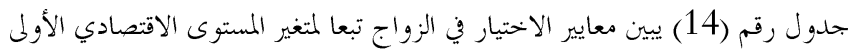

\begin{tabular}{|c|c|c|c|c|c|c|c|c|c|}
\hline \multicolumn{2}{|r|}{ الدين \% } & \multicolumn{2}{|c|}{ الحسب \% } & \multicolumn{2}{|r|}{ \% J山l } & \multicolumn{2}{|r|}{ الجمال \% } & & ت \\
\hline اكثر مر & اقل من & اكثر & اقل من & اكثر ـ & اقل من & اكثر مـ & اقل من & & \\
\hline مليون & مليون & مليون & مليون & مليون & مليون & مليون & مليون & 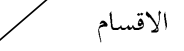 & \\
\hline 23.3 & 46.67 & 3.33 & 30.00 & 5.67 & 13.67 & 6.67 & 26.67 & اللغة العربية & 1 \\
\hline 33.2 & .62 & .4 & 49 & 2.00 & 4.76 & 3 & 28.57 & اللغة الإنكليزية & 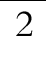 \\
\hline 26.66 & 33.33 & 26.66 & 33.33 & .88 & 8.88 & 26.67 & 24.44 & القانون & 3 \\
\hline 27.00 & 41.67 & 20.83 & 27.17 & 83 & 15.25 & 31.23 & 29.17 & $-g$ & 4 \\
\hline 18.67 & 50.00 & 22.83 & 3 & 7 & 0 & 7 & 33.33 & مالية ومصرف & 5 \\
\hline 33.33 & 33.33 & 18.18 & 24.24 & 12.12 & 12.12 & 36.36 & 36.36 & هندس & 6 \\
\hline 26.78 & 46.67 & 17.68 & 22.22 & 11.34 & 11.11 & 20.00 & 3333 & 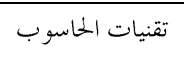 & 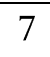 \\
\hline 27.27 & 47.67 & 12.12 & 34.43 & 3.03 & 6.06 & 12.12 & 36.3 & علوم حاسوب & 8 \\
\hline 13.33 & 45.78 & 13.33 & 32.89 & 8.87 & 4.45 & 17.78 & 17.89 & تربية & 9 \\
\hline 25.51 & 43.63 & 60 & 25 & 1 & 9.86 & 22.10 & 29 & المتوسط & \\
\hline
\end{tabular}

رسم بياني رقم (10) يوضح معايير الاختيار الزواجي وفقا للمتغير الاقتصادي للمرحلة الأولى

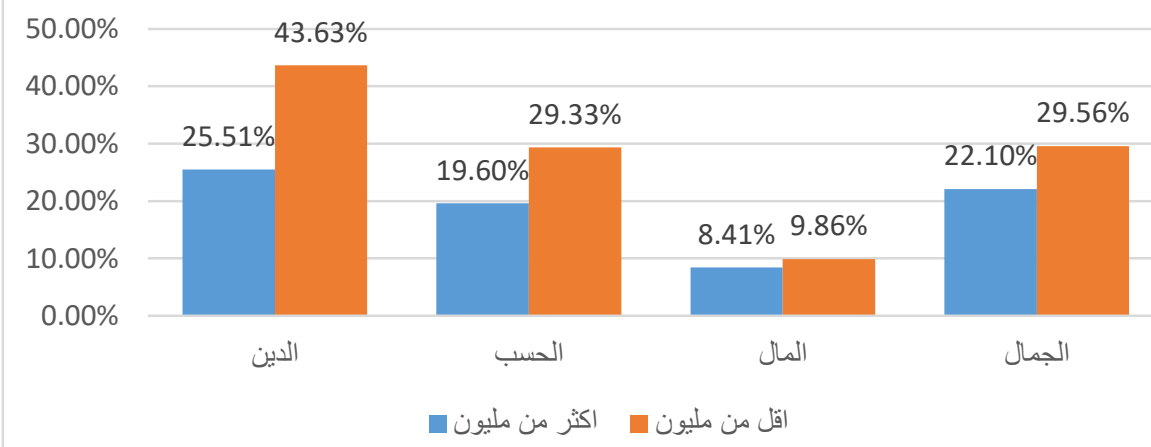


يكشف الجحدول السابق رقم (14) والرسم البياني رقم (10) عن وجود فروق في المتوسطات الحسابية

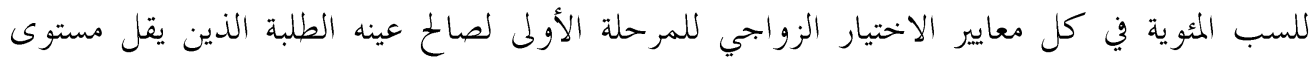
دخلهم الشهري عن مليون دينار عراقي في المعايير الأربعة فكان اعلاها معيار الدين حيث كان المتوسط

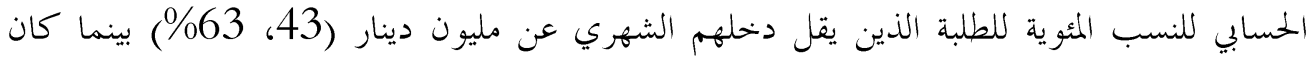

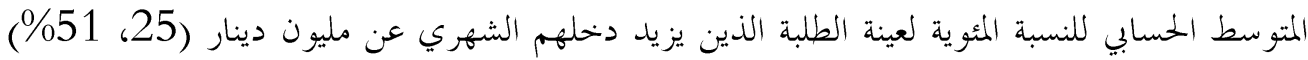
بفارق قدره (18، 12\%) وهذا فرق كبير واضح. ثم يليه معيار الحسب حيث كان المتوسط الحسابي

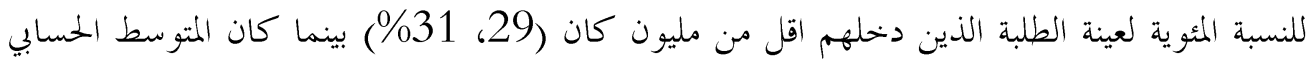

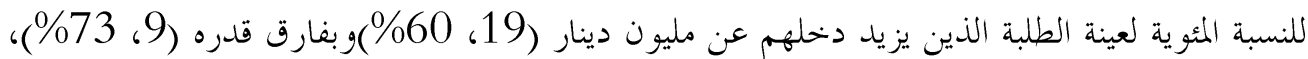

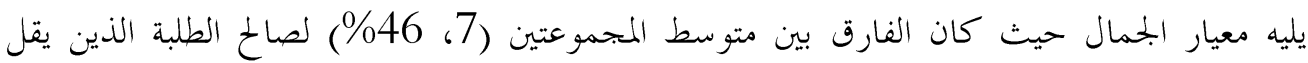

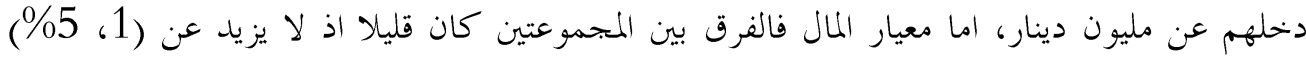
لصالح عينه الطلبة الذين يقل دخلهم عن مليون دينار.

\section{ث- نتائج المرحلة الثالثة حسب المستوى الاقتصادي:}

بعد استخراج المتوسطات الحسابية لمعايير الاختيار الزواجي لعينه طلبة المرحلة الثالثة في اقسام الكلية وفقا المتغير المستوى الاقتصادي كانت النتائج كما في الجحدول التالي رقم (15) والرسم البياني رقم (11)

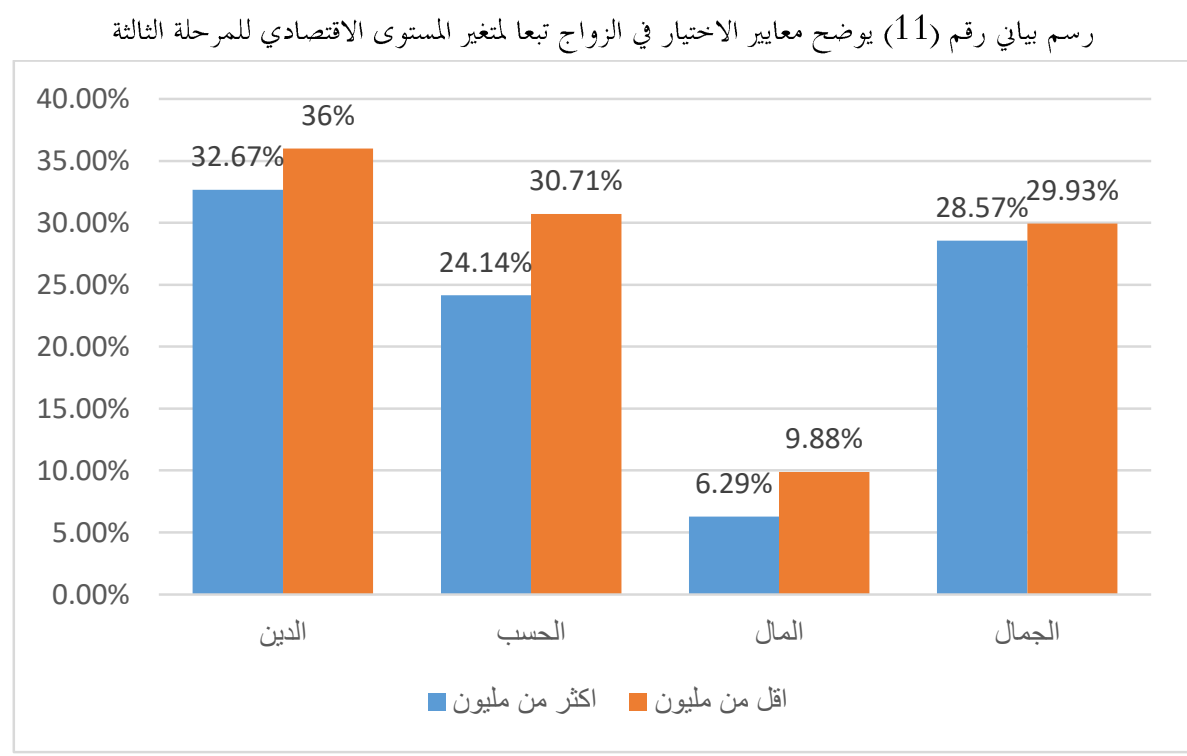


جدول رقم (15) يبين معايير الاختيار في الزواج تبعا لمتغير المستوى الاقتصادي للمرحلة الثالثة

\begin{tabular}{|c|c|c|c|c|c|c|c|c|c|}
\hline \multicolumn{2}{|r|}{ الدين \% } & \multicolumn{2}{|c|}{ الحسب \% } & \multicolumn{2}{|r|}{ \% Jلا } & \multicolumn{2}{|r|}{ الجمال \% } & & \\
\hline مليون من من & مليون من & مليون من من & مليون من & مليون من من & مليون مل من & مليون & مليون من & الاقسام & \\
\hline 41.70 & 23.83 & 37.50 & 23.50 & 8.30 & 8.33 & 37.50 & 20.83 & اللغة العربية & 1 \\
\hline 11.90 & 57.14 & 21.42 & 38.06 & 7.14 & 9.51 & 16.66 & 38.90 & اللغة الإنكليزية & 2 \\
\hline 33.33 & 24.75 & 21.10 & 34.91 & 8.19 & 12.51 & 17.46 & 26.98 & القانون & 3 \\
\hline 38.83 & 45.62 & 22.82 & 24.56 & 1.57 & 5.26 & 21.04 & 36.34 & تحليلات مرضية & 4 \\
\hline 44.43 & 34.92 & 25.39 & 34.92 & 4.76 & 3.07 & 28.57 & 23.81 & مالية ومصرفية & 5 \\
\hline 26.66 & 16.67 & 33.33 & 23.33 & 13.33 & 16.67 & 46.67 & 33.33 & ل بنية & 6 \\
\hline 37.50 & 52.08 & 16.67 & 37.50 & 2.80 & صفر & 29.00 & 29.17 & تقنيات حاسوب & 7 \\
\hline 23.33 & 43.33 & 23.33 & 40.00 & 6.67 & 6.67 & 26.67 & 26.67 & علوم حاسوب & 8 \\
\hline 37.25 & 35.67 & 15.67 & 19.61 & 3.75 & 17.94 & 23.53 & 33.33 & تربية بدنية & 9 \\
\hline 32.67 & 37.11 & 24.14 & 30.71 & 6.29 & 8.00 & 27.45 & 29.93 & المتو سط & \\
\hline
\end{tabular}

يو ضع الجحدول السابق رقم (15) والرسم البياني رقم (11) ان المتوسطات الحسابية للنسب المئوي لمعايير الاختيار الزواجي الأربعة لدى بحموعة طلبة المرحلة الثالثة الذين يقل دخلهم الشهري عن مليون دينار

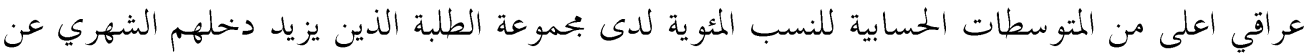

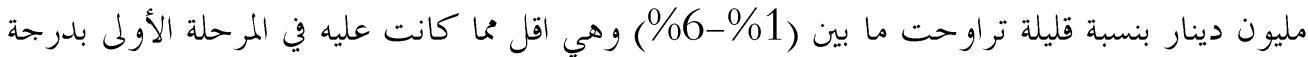

و واضحة.

\section{ج- نتائج المرحلتين الأولى والثالثة (العينية الكلية)}

وفقا لمتغير المستوى الاقتصادي بعد ضم المرحلتين الأولى والثالثة واستخراج المتوسطات الحسابية للنسب المبله

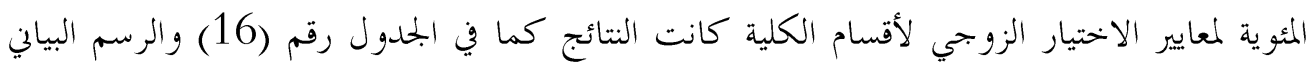

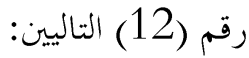


جدول رقم (16) ييين معايير الاختيار في الزواج تبعا لمتغير المستوى الدراسي الاقتصادي للعينة الكلية

\begin{tabular}{|c|c|c|c|c|c|c|c|c|c|}
\hline \multicolumn{2}{|r|}{ الدين \% } & \multicolumn{2}{|r|}{ الحسب \% } & \multicolumn{2}{|r|}{ \% المال } & \multicolumn{2}{|r|}{ الجمال \% } & & \\
\hline اكثر من & اقل من & اكثر من & اقل من & اكثر م. & اقل من & اكثر من & اقل من & & \\
\hline مليون & مليون & مليون & مليون & مليون & مليون & مليون & مليون & & \\
\hline 32.25 & 35.23 & 30.42 & 26.75 & 12.48 & 11.00 & 27.00 & 3.75 & اللغة العربية & \\
\hline 22.58 & 38 & & 28 & 2 & + & & 74 & اللغة الإنكليزية & \\
\hline 29.0 & & & & & 1 & 7 & 70 & ون & \\
\hline 32.92 & & & & & 7.8 & & & تحليلا & \\
\hline 31 & & & & & 7.78 & & & مالية ومصرفية & \\
\hline 30.00 & .00 & & 23.79 & .73 & 14.40 & 52 & 34 & هندسة مدنية & \\
\hline 32.3 & 4 & 17 & & 7.07 & 5.56 & 0 & 31.25 & تقنيات حاسوب & \\
\hline 25.30 & 35.00 & 1 & 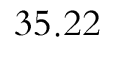 & 4.85 & 6.37 & 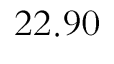 & 0 & علوم حاسوب & \\
\hline 33.79 & 40.74 & 14.51 & 27.25 & 6.31 & 11.20 & 20.66 & 25.61 & |تربية بدنية & \\
\hline 30.27 & 39.23 & 8 & 2 & 2 & 9.01 & 24.94 & .73 & المتو سط الحسابي & \\
\hline
\end{tabular}

رسم بياني رقم (12) يوضح معايير الاختيار في الزواج تبعا للمتغير الاقتصادي للمر حلتين الأولى والثالثة (العينة الكلية)

\begin{tabular}{|r|}
$45.00 \%$ \\
$40.00 \%$ \\
$35.00 \%$ \\
$30.00 \%$ \\
$25.00 \%$ \\
$20.00 \%$ \\
$15.00 \%$ \\
$10.00 \%$ \\
$5.00 \%$ \\
$0.00 \%$ \\
\hline
\end{tabular}

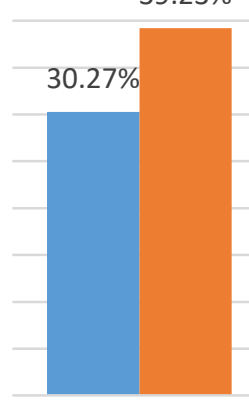

الدين
$29.90 \%$

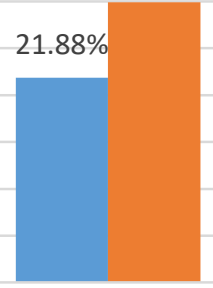

الحسب
$29.75 \%$

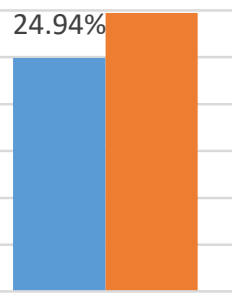

الجمال

\section{اقل من مليون ص اكثر من مليون}

بين الجحدول السابق رقم (16) ورسمه البياني رقم (12) ان المتوسطات الحسابية للنسب المئوية للمعايير الأربعة في اقسام الكلية لدى الطلبة الذين يقل دخلهم الشهري عن مليون دينار عراقي اعلى من رنم المتوسطات الحسابية للنسب المئوية لدى الطلبة الذين يزيد دخلهم الشهري عن مليون دينار بفارق 
مقداره (8، 96\%) لمعيار الدين، يليه معيار الحسب بفارق قدره (8، 03\%) ثم يليه معيار الجمال

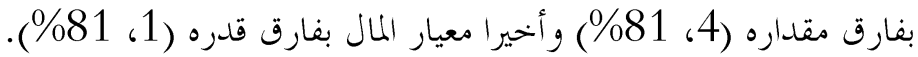
وبهذه النتائج نكون قد حققنا الهدف الرابع وفرضيته، اذ تأكد لنا عن وجود فروق بينه وعلاقة واضحة بين معايير الاختيار في الزواج تبعا للمتغير الاقتصادي اذ يبدو ان الطلبة الذين مستواهم الاقتصادي ادلى ودخلهم الشهري اقل من مليون كانت النسب المئوية لتفضيلهم ذات الدين، وذات الحسب، والجمال والمال، اعلى من النسب المئوية للطلبة الذين كان مستو اهم الاقتصادي اعلى ودخلهم الشهري اكثر من مليون دينار، ور.ما كان هذا تعويض الشعور ينقص المال بالدين والحسب ولمب الجمال، والله اعلم.

\section{الاستنتاجات:}

1- ان مسالة الاختيار في الزواج مسالة في غاية الصعوبة والتعقيد بالنسبة للذكور، لتعدد المعايير وتنوعها، كما لاحظ الباحث ان بعض أوراق الاستبانة فيها شطب وتغيير في الاختيارات او تعليق

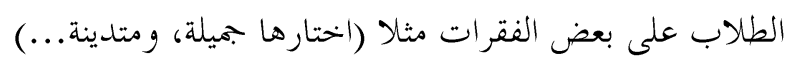

2- توصلت هذه الدراسة الى ان ترتيب معايير الاختيار في الزواج لطلاب الكلية كان معيار الدين في الصدارة المرتبة الأولى بنسبة (69,51)\% وهذا يشير الى ان الطلاب متمسكون بالقيم الدينية في الاختيار الزواجي، بالاضافة الى ان التدين يشكل سمة بارزة في حياة بحتمع محافظة الانبار. ثم يليه

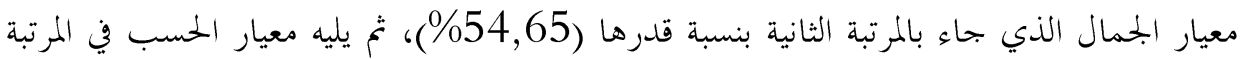

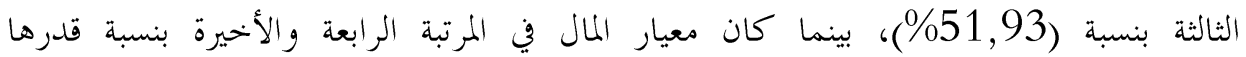
$(\% 16,02)$ 3- تباينت نسب معايير الاختيار في الزواج تبعا لبعض المتغيرات كالتخصص الدراسي لأقسام الكلية، و المراحل الدراسية، والمستوى الاقتصادي الاجتماعي، وبينت ان هنالك علاقة بين هذه المتغيرات والاختيار في الزواج. 1- تضمين المناهج التربوية و التعليمية موضوع الزواج وأهدافه و كيفية الحفاظ على استمراريته والمعايير المفضلة للاختيار في الزواج، وعرض بعض نتائج الدراسات العربية في تلك المناهج، وتدريسها في مرحلتي الدراسة الإعدادية والجحامعة ويمكن ان تكون ضمن بعض بعض بعض المواد الدراسية، او ان تكون تحت مسمى خاص لمقرر دراسي يمدده ذوي الاختصاص. 
2- اجراء دراسات تتناول معايير ومتغيرات أخرى، وفي جامعات أخرى او مراحل دراسة او في مناطق أخرى.

3- اجراء دراسات للتعرف على معايير الاختيار في الزواج للطالبات الاناث.

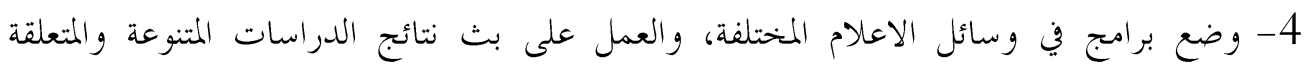
موضوع الزواج والاختيار الزوجي واجراء ندوات وحوار من اجل توعل توعية الشباب غير المتزوجين

$$
\text { واسرهم. }
$$

5- إقامة دورات تدريبية للمقبلين على الزواج من كلا الجنسين في بعض الجامعات العراقية او النظمات الاجتماعية من ذوي الاختصاص تتناول البناء الاسري وعو امل تماسكه، وتيسير إجراءات

الزواج

6- اثر التكنلوجيا والاتصالات على معايير الاختيار الزواجي.

التوصيات:

1- توعية الآباء والامهات على كيفية التعامل مع ابناهم عند الاقدام على الاختيار الزواجي وبيان اهم المعايير المثلى والاسس الفضلى في الاختيار الزواجي.

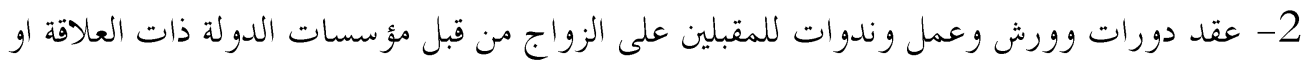
المساجد او منظمات المجتمع المدني لتوضيح حقوق الزوجين وواجباهم نهو بعضهم البعض. 3- توعية الأبناء من قبل الاسرة والمؤسسات ذات العلاقة على كيفية بناء العلاقات الزوجية ولتكن مبنية على المودة والرحمة كما أرادها الله تعالى. 4- على الشباب المقبل على الزواج استشارة ذوى الاختصاص والخبرة في مثل هذه الأمور الهامه والمعقدة. 5- انشاء مراكز متخصصة للإرشاد الزواجي تابعه للجامعات العر اقية.

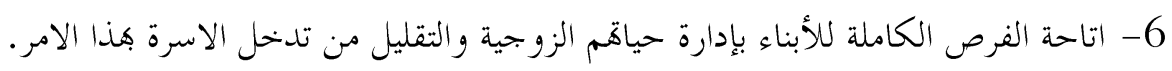

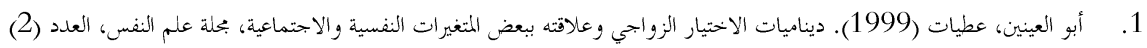

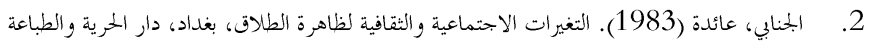

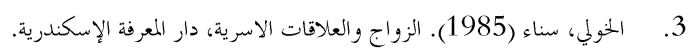

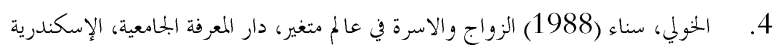

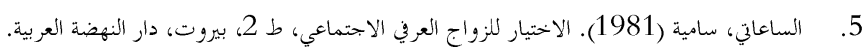


6.

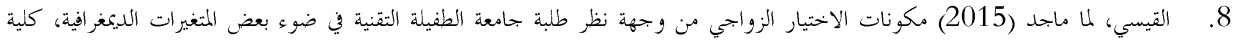

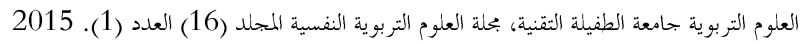

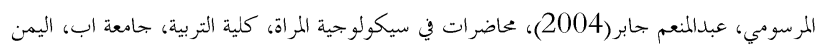

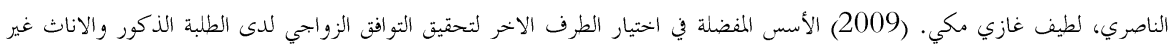

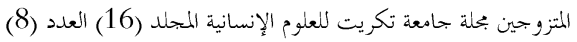
درويش، زينب.(2009) عحكات اختيار شريك الحياة وعلاقتها ببعض المتغيرات لدى طلاب الجامعة السعوديين والمصريين حوليات مركز

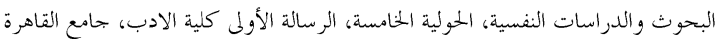

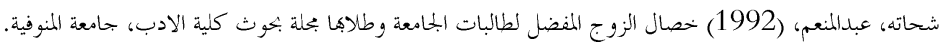

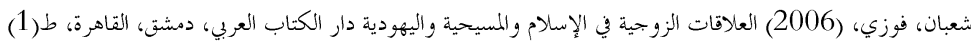

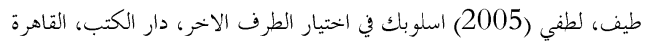

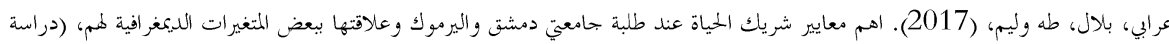

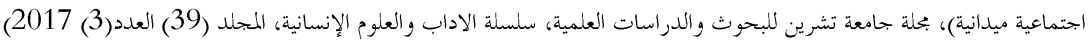

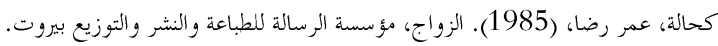
.16

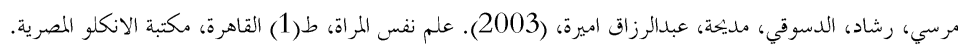

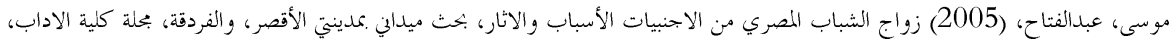

بقنا.

موسى، عبدالفتاح، (1408ه) البناء الاجتماعي للاسرة، المعهد العالي للخدمة

a timann,k: 2005 mate celeclion crierin amog muslim living in America evolution and humen ،Badahdah .

$432-440$ ،behavior 26(5)

j(1960:the family from instition to companions hip newyork ameri - can book ،Burges.e.w. lock Harvey

com pany zand edition)

Buss $\mathrm{d}$, sex differences in human mate preferences hypotheses tested in 37 cuntures behavioral and brain .22

siences 1989.5:12-49

1 (44). ‘Preferences and sexual strategu: test for evolution ary hypotheses Chinese journal of psychology .23

75-93

\section{ملحق رقم (1)}

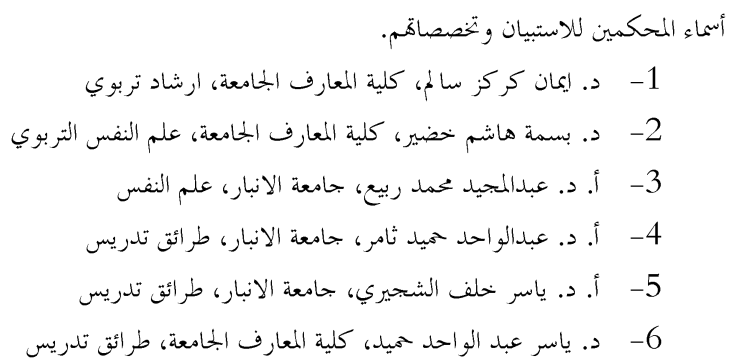




\section{الملحق رقم (2)}

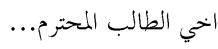
تحية طيبة....

يروم الباحث اجراء بحث بعنوان (معايير الاختيار في الزواج لدى الطلبة الذكور في كلية المعارف الجامعة)

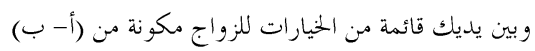
فضع علامة (صح ل) على خيار واحد اما (أ) او (ب) من كل زوج من الخيارات الذي تعتبره اكثر أهمية بالنسبة لك عند الاختيار في الزواج وتفضله على الاخر. املا ان تكون اجابتك بروية ودقة، وانا واثق ان اجابتك ستكون اكثر صدقا وامانه وموضوعية وثث ان الامر يتعلق بالبحث فقط من اجل تحقيق أهدافه، كما نرجو ان تملا المعلومات الخاصة ولكم منا الشكر والتقدير. المر حلة: أولى:

القسم:

السكن: مركز المدينة $\square$ اكثر من مليون الدخل الشهري للاسرة: اقل من مليون

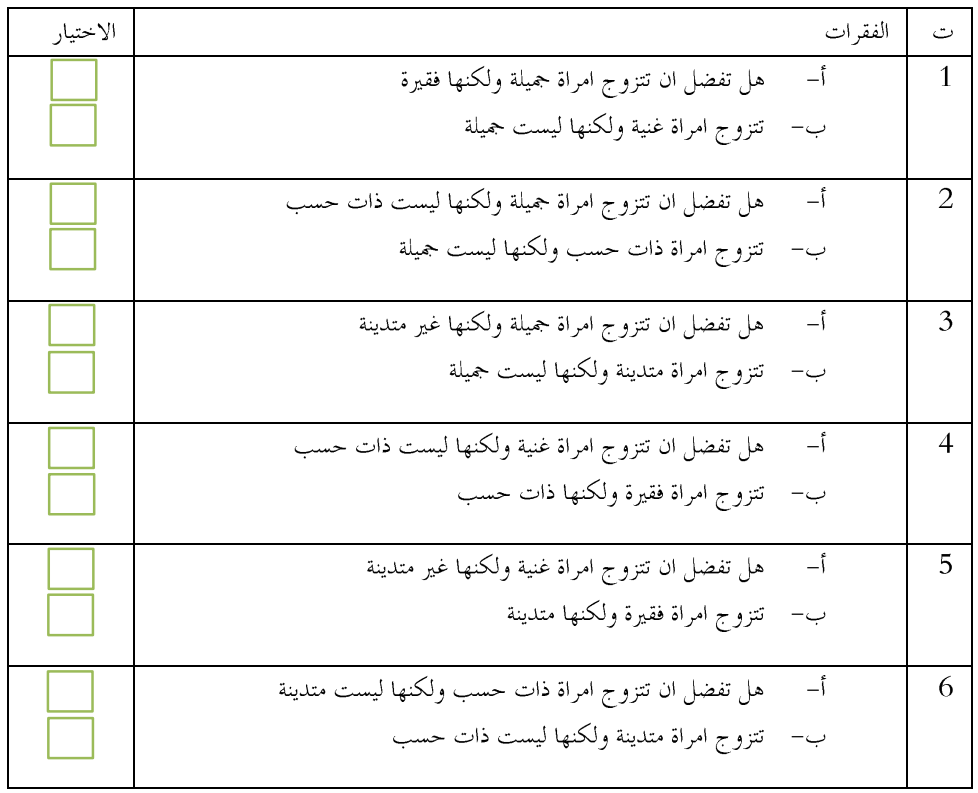

